H A R VAR D

\title{
Surviving the Global \\ Financial Crisis: \\ Foreign Direct Investment and Establishment \\ Performance
}

Laura Alfaro

Maggie Chen

\section{Working Paper}

10-110 


\title{
Surviving the Global Financial Crisis: Foreign Direct Investment and Establishment Performance*
}

\author{
Laura Alfaro ${ }^{\dagger}$ \\ Harvard Business School and NBER \\ Maggie Chen ${ }^{\ddagger}$ \\ George Washington University
}

June 2010

\begin{abstract}
We examine in this paper the differential response of establishments to the global financial crisis, with particular emphasis on the role of foreign direct investment (FDI) in determining micro economic performance. Using a new worldwide dataset that reports the activities of more than 12 million establishments before and after 2008, we investigate how multinationals around the world responded to the crisis relative to local firms. We explore three distinct channels through which FDI affects establishment performance, (i) production linkages, (ii) financial linkages, and (iii) multinational networks. Our analysis shows that while multinational owned establishments performed, on average, better than their local competitors, there is considerable heterogeneity in the role of FDI. First, multinationals located in countries that experienced sharper declines in aggregate output, demand, and credit conditions displayed a greater advantage over local firms. Multinationals headquartered in countries with a greater incidence of the crisis, in contrast, fared less satisfactorily abroad. Second, multinationals that engaged in activities with vertical production linkages or stronger financial constraints exhibited particularly better responses compared to local firms. Finally, being part of a larger multinational network also led to superior economic performance.
\end{abstract}

JEL codes: F2, F1

Key words: global financial crisis, establishment response, foreign direct investment, production linkage, financial linkage, network

\footnotetext{
${ }^{*}$ We thank participants at the Midwest International Economics Group Meeting and the IMF for valuable comments and suggetions. We are grateful to Dun \& Bradstreet and Dennis Jacques for helping us with the D\&B dataset and HBS and GW CIBER for financial support.

${ }^{\dagger}$ Email: lalfaro@hbs.edu; Phone: 617-495-7981.

${ }^{\ddagger}$ Email: xchen@gwu.edu; Phone: 202-994-0192.
} 


\section{Introduction}

In 2008-2009, the world economy suffered the deepest global financial crisis since World War II. Countries around the globe witnessed major declines in output, employment, and trade. GDP in industrial countries fell by 4.5 percent in 2008 , and average real GDP growth in emerging economies dropped from 8.8 percent in 2007 to 0.4 at the beginning of 2009 . The unemployment rate rose to 9 percent across OECD economies, and reached double digits in a mix of industrial and developing nations. World trade volume plummeted by more than 40 percent in the second half of 2008, collapsing at a rate that outpaced the fall of aggregate output.

Its severity led many economists to explore the macro patterns and causes of the recent crisis. Rose and Spiegel (2009), for example, investigate the role of trade and financial linkages in explaining the differential extent of the crisis across countries. Using a large country-level cross-section dataset, they do not find international linkages to be clearly associated with incidences of the crisis. Eaton et al. (2009) and Chor and Manova (2009), among others, examine the potential causes of the great trade collapse, a phenomenon that received particular attention in the recent crisis, and find, respectively, that manufacturing demand and credit conditions played important roles. ${ }^{1}$

Less stressed in this debate is the performance of foreign direct investment (FDI) and its role in the global financial crisis. In 2008, multinationals' foreign affiliate sales fell by 4.6 percent, in sharp contrast to the 24 percent growth rate the year before (see UNCTAD, 2009). Similarly, the growth rate of foreign affiliate production dropped from 20 percent in 2007 to -4.4 percent in 2008. Exports of foreign affiliates performed exceptionally well compared to the other indicators, and sustained a robust growth rate of 15 percent even in the midst of the world trade collapse. These observations suggest that multinational corporations are likely to exhibit a complex pattern of responses to the crisis.

An evaluation of these patterns poses several challenges, however. First, it is difficult to disentangle the effect of FDI from other macroeconomic factors such as market demand, trade integration, and credit conditions. Second, the channels through which FDI affects economic performance are likely to be masked in aggregate data. Third, many national sources, especially in less developed nations, lag considerably in assembling aggregate economic data including data on FDI. ${ }^{2}$

In this paper, we investigate the role of foreign direct investment in determining micro economic responses to the crisis. In contrast to existing studies of the recent crisis, which focus on aggregate economic outcomes at country and industry levels, we use a new worldwide

\footnotetext{
${ }^{1}$ Baldwin and Evenett (2009) compile some of the leading explanations.

${ }^{2}$ For example, the latest UNIDO INDSTAT 2009 Database, an authority industry-level data source, reports industrial data only up to 2007. The OECD STAN Database, another widely used industry-level dataset, currently provides 2008 data for only 13 OECD countries.
} 
dataset that reports operational activities of more than 12 million establishments before and after 2008 to examine patterns of economic crisis at the most disaggregated level. We study how multinationals around the world responded to the crisis relative to local firms, and the underlying mechanisms of the differential responses. The use of establishment level data enables us to explore variations within the same country and industry, and separate the effect of foreign direct investment from macroeconomic factors. The worldwide coverage enables us to exploit heterogeneity across countries, industries, and individual multinationals to identify the channels through which FDI affects economic performance.

The importance of examining the role of FDI in the global financial crisis is highlighted by the proliferation of multinational activities in recent decades. As of 2007, FDI inflow represented nearly 17.2 percent of total capital formation in developed nations, and 13 percent in developing economies. Multinationals' foreign affiliate production was equivalent to 12 percent of the world's total GDP, with exports accounting for one third of the world's total exports.

Despite its prevalence, how FDI affects macro and micro economic performance remains unclear. At the macro level, the literature finds only weak support for an exogenous positive effect of FDI on economic growth. Existing evidence shows the effect of FDI to be strongly conditional on local conditions such as human capital and financial sector development (see, for example, Borensztein et al., 1998; Alfaro et al., 2004; Carkovic and Levine, 2005). Evidence at the micro level suggests a more adverse effect. Most studies find FDI to have a significant negative effect on plant survival and stability. It is argued that MNCs' footloose nature makes them more volatile than purely domestic firms. Görg and Strobl (2003), for example, find Irish establishments with foreign ownership to be more likely than indigenous plants to exit the market controlling for other plant and industry specific characteristics. Gibson and Harris (1996) and Bernard and Sjoholm (2003) reach similar conclusions for New Zealand and Indonesia, respectively. Bernard and Jensen (2007) focus on domestic multinationals in the U.S. and find them to be more likely than non-multinational firms to shut down home-country plants.

Our paper explores three distinct channels through which FDI can affect establishment performance. First, we consider a production linkage channel. In a time of crisis, multinationals can react to adverse shocks by adjusting home and foreign production. This can either exacerbate or alleviate the impact of the crisis on affected establishments, depending on the nature of production linkages between headquarters and the establishments. If the establishments' production activities duplicate those of headquarters, firms will be more likely to respond to negative shocks by shifting production back home. If establishments instead share a vertical production linkage with headquarters, shocks that occur in the establishments' host countries (e.g., a decline in local demand) can be partly absorbed by headquarters, leading to a more resilient response to crisis. Conversely, shocks that occur in multinationals' 
home countries can be transmitted to MNCs' foreign establishments, occasioning a negative spillover. Vertical production linkages are thus more likely to exert a positive effect when host countries experience a large contraction in demand and MNCs' home countries do not. ${ }^{3}$

Second, we consider a financial linkage channel. Foreign-owned establishments can be less dependent on host-country credit conditions because of the supply of capital from headquarters. This type of financial linkage, by enabling multinational owned establishments to tap into international credit markets, supports capital market diversification, an advantage particularly important when the incidence of a financial crisis is great in host countries but small in MNC home countries and when establishment activities tend to be financially constrained. Financial, like production, linkages between MNC foreign establishments and headquarters can transmit financial shocks in MNCs' home countries to their foreign establishments.

Finally, we examine how the effects of production and financial linkages can be amplified through multinational networks. Most multinational firms today operate a plurilateral production and financial network. Having a large multinational network enables multinationals to diversify both production and financial markets, which can either sustain or lower the economic stability of individual establishments depending on the nature of the linkages across the network.

Our analysis broadly supports the above hypotheses. We find responses to crisis to differ sharply between multinational and local firms. Establishments with multinational ownership perform, on average, better than local competitors, but there is considerable heterogeneity in the role of foreign direct investment. First, the role of foreign direct investment varies with the incidence of the crisis in host and home countries in a pattern consistent with the production and financial linkages hypotheses. Multinationals located in host countries that have experienced sharper declines in aggregate demand and credit conditions displayed a greater advantage over local firms in economic performance. In contrast, multinationals headquartered in countries with a greater incidence of the crisis, including lower demand and worse credit conditions, fared less satisfactorily overseas, suggesting a potential spillover of home-country shocks.

Second, the effect of foreign direct investment varies with attributes of multinational activities, in particular, the production linkage between foreign establishments and headquarters and the financial constraint that faces foreign establishments. MNC subsidiaries that shared vertical production linkages with parent firms exhibited more resilient performance while horizontally linked subsidiaries responded less positively. Albeit previously unidentified, this result is not entirely unexpected. Bernard et al. (2009) have shown that intra-firm trade fell

\footnotetext{
${ }^{3}$ By examining the effect of vertical production linkages on establishment performance, our work adds to the debate on the link between vertical integration and the great trade collapse. Bems, Johnson and Yi (2010), investigating the role of global supply chains, argue that increasing vertical specialization contributes to the greater contraction of world trade relative to total output. Bricongne, Fontagnè, et al. (2009) present an alternative argument and show that the extensive presence of supply chains does not automatically explain why world trade overshot the drop in world GDP.
} 
less than unrelated-party trade during the Asian financial crisis. Multinationals that engaged in activities with stronger financial constraints also have a greater advantage over local firms. These results lend direct support to the role of production and financial linkages in explaining the differential responses of multinational and local firms.

Finally, we find the size of multinational networks also matters. Being part of a larger multinational network, on average, was associated with superior economic performance during the crisis. But there is a negative interdependence across establishments with horizontal production linkages. A better performance of third countries in which MNCs performed duplicate activities is found to lower the advantage of multinational ownership in a given host country. Foreign establishments also generate spillovers to headquarters. A larger number of horizontal foreign subsidiaries decreased the positive effect of outward FDI on headquarters performance.

The average positive effect of FDI on establishment performance can, however, result from a self-selection bias. It is possible that MNCs have acquired more productive local firms and, as a result, perform better during the crisis. To address this concern, we employ a matching technique to create the counterfactual of MNC owned establishments. We match each MNC establishment with a local firm based on economic characteristics such as sales, age, and exporter status as well as location and industry factors. Each matched pair shared similar economic attributes prior to the crisis, except the status of foreign ownership. Comparing the performance of the matched establishments at the end of 2008, we find the effect of foreign ownership to remain significant: MNC owned establishments exhibited, on average, better economic performance than their local matches during the crisis.

Micro evidence of the role of FDI in economic crises is scarce. Relatively few studies have examined how multinationals respond to the crisis compared to local firms, and how MNCs link establishment performance across countries. Alvarez and Görg (2007), investigating the response of multinational and domestic firms to an economic downturn in Chile, do not find multinationals to react to the economic crisis differently than domestic firms. Desai, Foley and Forbes (2008), evaluating the response of multinational and local firms to sharp currency depreciations, find sales, assets, and investment to increase significantly more for U.S. multinational affiliates than for local firms. Different from these studies' focus on regional economic slowdowns and currency depreciations, our analysis draws from the recent global financial crisis. We look to the global coverage and considerable heterogeneity of the recent crisis to explain the role of FDI in determining micro economic performance and disentangle some of the ambiguities in previous findings.

Also exploring the recent crisis, Tong and Wei (2009) examine whether the volume and composition of capital flows affected the degree of credit crunch faced by a country's manufacturing firms. Using data on 3,823 firms in 24 emerging countries, the authors find declines in stock prices to be, on average, more severe for firms intrinsically more dependent on external 
finance. The volume of capital flows had no significant effect on the severity of the credit crunch, but the composition of capital flows mattered: pre-crisis exposure to non-FDI capital inflows worsened the credit crunch whereas exposure to FDI alleviated liquidity constraints. In this paper, we document the roles of production linkages and multinational networks, as well as of financial linkages. By taking into account establishments both at the epicenter and on the periphery of the crisis, our analysis also considers multinationals' role as an international linkage in transmitting economic shocks. In this vein, our work contributes to the extensive literature of international financial crises by offering micro-level evidence of the role of multinationals as a potential transmission mechanism (see, e.g., Eichengreen et al., 1996; Glick and Rose, 1999; Kaminsky et al., 2001; Forbes, 2004).

We organize the rest of the paper as follows. We describe the dataset in Section 2, and patterns of establishment performance by firm structure, country, and industry in Section 3. The econometric analysis and empirical evidence are presented in Sections 4 and 5, respectively, and the sensitivity analysis in Section 6. Section 7 concludes.

\section{Data and Empirical Framework}

\subsection{The WorldBase Database}

We employ, for our empirical analysis, WorldBase, a new worldwide establishment dataset complied by Dun \& Bradstreet (D\&B) that covers public and private enterprises in more than 100 countries and territories. We compile the 2007 and most recent 2009 editions of WorldBase to obtain information on establishments before and during the global financial crisis.

Dun \& Bradstreet has been the leading source of commercial credit and marketing information since $1845 .{ }^{4}$ D\&B presently operates in more than a dozen countries and territories either directly or through affiliates, agents, and associated business partners, and compiles data from a wide range of sources including public registries, partner firms, telephone directory records, and websites. All information is verified centrally via a variety of manual and automated checks. Early uses of D\&B data include Caves' (1975) size and diversification pattern comparisons between Canadian and U.S. domestic plants and subsidiaries of U.S. multinationals in Canada, and Lipsey's (1978) comparisons of D\&B data with existing sources with regard to the reliability of U.S. data. More recently, Harrison, Love, and McMillian (2004) use D\&B's cross-country foreign ownership information. Other research that has used D\&B data includes Black and Strahan's (2002) study of entrepreneurial activity in the United States, Acemoglu, Johnson, and Mitton's (2009) cross-country study of concentration and vertical integration, and Alfaro and Charlton's (2009) analysis of vertical and horizontal activities of

\footnotetext{
${ }^{4}$ For more information, see: http://www.dnb.com/us/about/db_database/ dnbinfoquality.html.
} 
multinationals.

D\&B's WorldBase, albeit not without problems, offers an ideal data source for the research questions posed in this study, providing several distinct advantages over alternative data sources. First, the unit of observation in WorldBase is the establishment (a single physical location at which production operations or services are performed) instead of the firm. Establishments have their own addresses, business names, and managers, but might be partly or wholly owned by other firms. The database supports the linking of establishments to firms using information on domestic and global parents and the DUNS identification. ${ }^{5}$ Establishment-level operation and ownership information is central to our goal of examining the role of foreign direct investment in determining establishment performance.

Second, the dataset used in this project covers a larger number of countries than alternative data sources, enabling to perform a comprehensive analysis of the crisis for developed as well as developing nations both at the epicenter and on the periphery of the crisis. It allows us to investigate how the role of FDI varies across countries with heterogeneous incidences of the crisis.

Third, the dataset provides the most recent information on establishment activities. Most national sources, especially in less developed nations, lag considerably in assembling aggregate economic data. This presents a significant challenge for analyzing the recent crisis. WorldBase, in contrast, contains updated 2008 operational information for more than 12 million establishments worldwide. Although this coverage still does not reflect the world population, its breadth and timeliness are unique compared to alternative data sources.

We use the 2007 and 2009 editions of WorldBase, time variation between which enables us to identify establishment performance during the 2007-2008 period. We make a number of exclusions. First, we drop records that lack primary industry classification and starting year information. Second, we restrict the data to establishments that report sales information for both time periods. Moreover, we include only establishments with positive sales and employment in 2007. Requiring positive employment helps to exclude establishments registered exclusively for tax purposes as well as self-employment businesses. These types of establishments constitute a significant share of businesses in countries such as the United States. Finally, we drop agricultural and mining industries as well as countries with fewer than 100 observations. These criteria result in a final sample of 12,216,966 establishments in 53 countries.

We use four categories of information for each establishment: (i) industry information including the 4-digit SIC code of the primary industry in which each establishment operates and, for most countries, the SIC codes of as many as five secondary industries, listed in descending order of importance; (ii) ownership information including the establishments' domestic and

\footnotetext{
${ }^{5}$ To identify businesses numerically for data-processing purposes, D\&B introduced in 1963 the Data Universal Numbering System (the D-U-N-S Number). The system supports the linking of plants and firms across countries and tracking of plant histories including name changes.
} 
global parents, status (joint-venture, corporation, partnership), and position in the hierarchy (branch, division, headquarters); (iii) location information including country, state, city, and street address; (iv) operational information including sales, employment, and export status.

\subsection{Empirical Framework}

The measure of establishment performance considered in this paper is the percentage change of sales from 2007 to 2008, denoted as $d$ Sales $_{i}$. We define below the primary establishment-level variables used to explain the heterogeneous performance.

Ownership structures We account for three types of firm ownership structure. First, we identify units that are part of multi-establishment firms. An establishment is considered to belong to a multi-establishment firm if there exists at least one other establishment with the same firm owner, that is,

$$
\text { multi_estab }_{i}=\left\{\begin{array}{ll}
1 & \text { if } \exists \text { at least one other establishment with the same firm owner ID } \\
0 & \text { otherwise }
\end{array} .\right.
$$

Second, we identify establishments of foreign multinationals. An establishment is considered foreign multinational owned if its ultimate firm owner is based in a different country, that is,

foreign_$M N C_{i}=\left\{\begin{array}{ll}1 & \text { if firm owner is based in a different country than establishment } i \\ 0 & \text { otherwise }\end{array}\right.$.

Third, we consider establishments of domestic multinationals. Ultimate firm owners in this category are based in the same country as the establishment, but have operational units in other countries, that is,

$$
\text { domestic_MNC }=\left\{\begin{array}{l}
1 \text { if firm owner is based in the same country and } \exists \text { at least one } \\
\text { foreign establishment with the same firm owner ID } \\
0 \text { otherwise }
\end{array} .\right.
$$

Production linkages In addition to separating foreign MNC ownership from the other types of ownership structures, we distinguish the production linkage between establishments and foreign parent firms. We follow Acemoglu et al. (2009) and Alfaro and Charlton (2009) in considering two types of MNC subsidiaries: horizontal and vertical.

First, we identify subsidiaries that engage in final-good production, also referred to as subsidiaries with a horizontal linkage. We do this by comparing each subsidiary's primary product with the parent firm's primary products, all reported at SIC 4-digit level. If the subsidiary's primary product is listed as one of the parent firm's final products, it is considered 
a horizontal subsidiary.

$$
\text { horizontal }_{i}=\left\{\begin{array}{ll}
1 & \text { if } i \text { 's primary product } \in\{\text { parent firm's final products }\} \\
0 & \text { otherwise }
\end{array} .\right.
$$

We identify subsidiaries that share a vertical production linkage with parent firms by examining the input-output relationship between the subsidiary's primary product and the parent firm's final products. A subsidiary is considered vertical if the direct requirement of the subsidiary's primary product in the parent firm's final-product production exceeds a threshold value $0.1 .^{6}$

$$
\text { vertical }_{i}=\left\{\begin{array}{ll}
1 & \text { if the direct use of } i \text { 's primary product in parent firm's } \\
& \text { final-product production }>0.1 \\
0 & \text { otherwise }
\end{array} .\right.
$$

Financial constraints Unlike production linkages, financial linkages between subsidiaries and parent firms are not observed in the data and difficult to quantify. To examine the financial channel, we construct a proxy of external finance dependence and investigate how the effect of FDI varies with establishments' reliance on outside capital. We follow Braun (2003) in constructing this proxy, denoted as financial $_{k}$, for each establishment's primary industry. The variable is computed, for each industry, using the median firm's ratio of capital expenditures less cash flow from operations, that is,

$$
\text { financial }_{k}=\text { median }_{k}\left\{\frac{\text { capital expenditure }- \text { cash flow from operation }}{\text { capital expenditure }}\right\} \text {. }
$$

The variable is constructed based on worldwide data of publicly listed companies obtained from Global COMPUSTAT.

Multinational networks Finally, we take into account the size of firms' multinational networks to determine whether larger international networks affect establishments' economic performance. We construct a variable to measure the number of countries in which each firm operates, that is,

network $k_{i}=$ the number of countries in which $i$ 's firm owner operates.

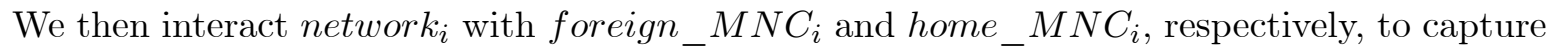
the effects of multinational networks on foreign- and home-country MNC establishments. We also identify, for each MNC subsidiary, the subset of the MNC network that performs identical

\footnotetext{
${ }^{6}$ We also considered different threshold values and found the results relatively similar.
} 
production activities:

$$
\begin{aligned}
& \text { horizontal_network } k_{i}=\text { the number of countries in which } i \text { 's firm owner } \\
& \text { duplicates } i \text { 's production. }
\end{aligned}
$$

This enables us to separate the effects of horizontal and vertical production linkages.

Establishment economic characteristics In addition to firm ownership and organization structures, we take into account a variety of establishment-level economic characteristics, including sales, age, multi-product status, and exporter status obtained from a lagged period. We use lagged sales to control for each establishment's size and efficiency. We also considered alternative measures such as employment size, market share, and labor productivity. The results were qualitatively similar. In addition, we include each establishment's age and examine whether a longer history of operation corresponded to a better response to the crisis. We also control for each establishment's multi-product status by constructing an indicator variable to represent establishments that produce more than one product. This variable informs us whether product diversification helps establishments achieve greater sustainability. Finally, we include an indicator variable to separate exporting establishments from establishments that sell only domestically. This variable helps capture the role of export participation in determining establishment performance.

Accounting for these above economic characteristics enables us to identify the role of FDI. Existing evidence (e.g., Helpman, Melitz and Yeaple, 2004) suggests that MNC owned establishments tend to be larger and more efficient than local firms. Taking into account establishment size and efficiency helps to separate the effects of FDI and other economics characteristics.

Finally, we control for all macro-level, country-industry specific factors such as market demand, credit conditions, and country linkages to the United States using a vector of countryindustry dummies. This enables us to focus on cross-establishment variations within each country and industry, and establish the relationship between establishment attributes and performance. In Section 5.1, we consider several measures of incidence of the crisis to explore the heterogeneous effect of FDI across countries and underlying mechanisms.

\section{Patterns of Establishment Performance in 2007-2008}

We now describe the patterns of establishment performance across countries and industries. Specifically, we explore how domestic and foreign owned establishments responded differently to the crisis. 


\subsection{Cross-Country Patterns}

We first consider a cross-country comparison. Figure 1 depicts the sales distribution of establishments in a group of industrial countries. In the United States, the distribution of domestically owned establishments became slightly less dispersed during 2007-2008, whereas the distribution of foreign MNC establishments shifted slightly rightward. In the United Kingdom, the distributions of domestic and foreign owned establishments were similarly affected, both with limited changes. Observation in France largely resembles those in the U.S. and the U.K.

[Figure 1 about here]

Netherlands exhibited a distinctively different pattern. The sales distribution of domestic establishments in Netherlands shifted significantly leftward, suggesting a decline in sales along most percentiles of the distribution. The distribution of foreign MNC establishments shifted rightward, with increased sales along most percentiles. This sharp contrast implies that in Netherlands, MNC owned establishments fared significantly better than their local counterparts. In Japan, domestic establishments exhibited little change in the sales distribution. For foreign MNC establishments, most of the distribution shifted slightly rightward, with an extended left tail suggesting a drop in sales for the lowest-percentile establishments.

Australia is one of the few industrial countries that saw a positive shift in the distributions of both domestic and foreign owned establishment with sales rising significantly across the board, regardless of ownership type. This observation is consistent with aggregate-level evidence. Australia's macro performance in GDP growth rate, employment rate, and trade volumes was significantly superior to that of most other industrial economies.

Now consider developing countries (Figure 2). In contrast to most developed nations, China exhibited clear positive shifts in sales distributions, with both domestic and foreign owned establishments experiencing increased sales in 2007-2008. This was also the case in India and Brazil, two other major developing countries, the magnitude of the positive shift being smaller in Brazil, with an extended left tail suggesting an adverse effect on sales of the lowest-percentile establishments.

[Figure 2 about here]

The responses of domestic and foreign owned establishments differed sharply in the Czech Republic, a major FDI recipient in eastern Europe since joining the European Union. The distribution of domestic establishments shifted slightly leftward while the distribution of MNC establishments experienced a positive movement, expanding the gap between domestic and

foreign owned establishments. In Mexico, neither type of distribution was significantly differ- 
ent in 2008. There was little change in the distribution of MNC establishments, and only a slight rightward shift in the distribution of domestic establishments. ${ }^{7}$

\subsection{Cross-Industry Patterns}

The response of domestic and foreign establishments also varies across industries. Figure 3 plots the distributions of domestic and foreign owned establishments across major manufacturing and services industries. In the textile and apparel industry, while there were mixed and somewhat negative responses among domestic establishments, the sales distribution of foreign owned establishments shifted rightward. An exception is the extended left tail of the foreign establishment distribution, suggesting that sales contracted for the lowest percentile establishments. A similar pattern is observed in the chemical industry and in the machinery and electronics industries.

[Figure 3 about here]

In the metal industry, an unambiguously positive movement was observed for foreign owned, and a clear negative movement for domestic, establishments. Foreign MNC establishments' overall performance in 2007-2008 was superior to that of domestically owned establishments. This observation also holds for the transportation equipment industry, with establishments owned by foreign MNCs generally experiencing growth in sales and domestically owned establishments showing a mixed response.

A similar pattern is observed in services. In the financial services industry, domestically owned establishments shifted slightly leftward while foreign MNC establishments shifted rightward. In the wholesale and retail industries, the pattern is similar except for the extended left tails of MNC establishments in both industries.

\section{FDI and Establishment Performance: Baseline Evidence}

To systematically evaluate the role of FDI in determining establishment performance during the recent global financial crisis, we first consider the following baseline empirical specification:

$$
\begin{aligned}
\text { SSales }_{i c k} & =\alpha+\beta_{1} \text { multi_estab }{ }_{i c k}+\beta_{2} \text { foreign_MNC } C_{i c k}+\beta_{3} \text { domestic_MNC } C_{i c k} \\
& +\gamma X_{i c k}+\lambda_{c k}+\varepsilon_{i c k}
\end{aligned}
$$

where $d$ Sales $_{i c k}$ denotes the percentage change in sales for establishment $i$ in country $c$ and industry $k$, multi_estab ${ }_{i c k}$, foreign_ $M N C_{i c k}$, and domestic_MNC $C_{i c k}$ represent establish-

\footnotetext{
${ }^{7}$ One other notable observation is that the sales distribution of MNC establishments dominates the distribution of domestic establishments in each country. Put differently, sales tend to be greater for MNC establishments than for their local competitors, which highlights the importance of controlling for establishment-level economic characteristics when examining the role of MNC ownership.
} 
ment $i$ 's ownership structure as defined in Section 2.2, $X_{i c k}$ is a vector of establishment characteristics that includes lagged sales, age, multi-product status, and exporter indicator, and $\lambda_{c k}$ represents a vector of country-industry dummies that control for all country-industry specific factors.

We begin by focusing on establishments located in the U.S., the principal origin of the crisis, then move on to the rest of the world to examine how establishments outside the U.S. were affected. We first establish the average effect of FDI, then explore the different channels through which FDI affects establishment performance.

\subsection{Inside the Origin of the Crisis}

Table 1 reports the estimates for establishments located in the U.S. A few regularities emerge in the table. First, establishments that were part of multi-establishment firms experienced greater growth in sales. According to column (1), the average percentage change in sales was 11 percentage points higher for these establishments than for establishments that operated alone. When controlling for foreign MNC ownership, we find the percentage change in sales for establishments owned by foreign MNCs to be 87 percentage points higher than for U.S. multi-establishment units, and 96 percentage points higher than for stand-alone establishments. Moreover, the average sales percentage change for establishments that belonged to U.S. multinationals was 26 percentage points higher than for establishments that belonged to domestic multi-unit firms.

[Table 1 about here]

These results are robust to controlling for a variety of establishment-level attributes. The estimates reported in columns (4) and (5) of Table 1 indicate that plants with greater lagged sales experienced less growth. Older, multiproduct plants performed more satisfactorily. Exporters, as suggested in column (5), performed better, achieving a sales growth rate 22 percentage points higher. Controlling for economic characteristics does not change the estimated role of FDI. Establishments owned by U.S. and non-U.S. multinationals performed significantly better than the other types of establishments.

\subsection{Outside the Origin of the Crisis}

As can be seen in Table 2, the role of foreign MNC ownership is similar, albeit smaller, for establishments outside the U.S. Establishments that were part of multi-establishment firms experienced about 6 percentage points higher percentage change in sales than establishments that operated alone (Table 2, columns (1)-(3)). Establishments owned by foreign MNCs exhibited an even greater advantage over their local counterparts. The average percentage change in sales for foreign MNC establishments was 7 percentage points higher than for 
establishments owned by domestic multi-unit firms, and 13 percentage points higher than for stand-alone units. The advantage of foreign MNCs was, however, significantly lower in non-U.S. countries than in the U.S. Home establishments of MNCs also exhibited superior performance, achieving sales growth rates 8 percentage points higher than those of domestic multi-establishment units that did not have overseas operations and 15 percentage points higher than those of domestic stand-alone units.

[Table 2 about here]

Controlling for establishment-level economic characteristics, again, does not change the main results. As in the U.S., establishments in the rest of the world with greater lagged sales had lower sales growth rates, and multiproduct establishments performed more satisfactorily. But in contrast to the U.S., younger establishments outperformed old establishments, posting, on average, higher sales growth rates. Exporters, again, fared better, on average, during the crisis, achieving sales growth rates 8 percentage points higher than those of non-exporters. Foreign ownership continues to have a significant effect: the sales growth of foreign owned establishments was 24 percentage points higher than that of other multi-establishment units. Domestic MNC ownership also continues to play a significant role, establishments owned by multinationals based in the same country outperforming other domestic multi-unit establishments by 35 percentage points.

\section{$5 \quad$ FDI and Establishment Performance: Main Channels}

Having examined the average effect of FDI, we now explore the different channels through which FDI affects establishment performance. As described in Section 1, we consider three distinct mechanisms, including production linkages, financial linkages, and multinational networks. These mechanisms form the basis of three main hypotheses predicting the heterogeneous effects of FDI across countries, industries, and firms.

\subsection{Dependence on the Incidence of the Crisis}

First, owing to production and financial linkages between subsidiaries and parent firms, we expect multinational owned establishments to exhibit a greater advantage over local firms when the incidence of the crisis is large in host countries but small in MNCs' home countries. This hypothesis applies to the incidence of the crisis in both demand and financial conditions. When the host country experiences a contraction in demand, we expect multinational owned establishments to be less affected when they share vertical production linkages with homecountry headquarters. Similarly, when the host country's capital supply contracts, MNC subsidiaries are expected to be less affected because of their financial linkages to home countries. For the same reasons, the performance of MNC subsidiaries will be crucially dependent 
on demand and financial conditions in their home countries. A better condition at home will enhance MNCs' advantage abroad; a worse incidence of the crisis in home economies will lead to negative spillovers to MNC foreign subsidiaries. The above hypothesis is summarized as follows:

Hypothesis 1 The effect of FDI increases in the host country's incidence of the crisis and decreases in that of the home country.

\subsubsection{Host-Country Incidence of the Crisis}

To test hypothesis 1, we first explore the relationship between the effect of FDI and the host-country incidence of the crisis by estimating the following equation:

$$
\begin{aligned}
d \text { Sales }_{i c k} & =\alpha+\beta_{1} \text { multi_estab }_{i c k}+\beta_{2 c} \text { foreign_MNC } C_{i c k}+\beta_{3} \text { home_MNC } C_{i c k} \\
& +\gamma X_{i c k}+\lambda_{c k}+\varepsilon_{i c k}
\end{aligned}
$$

where we allow the effect of FDI to vary across host countries and obtain an estimate of $\beta_{2 c}$ for each host country.

We then relate the host-country specific effects of FDI to the incidence of the crisis in the host countries. Four measures of macroeconomic conditions, denoted as condition , are considered, (i) estimated host-country-industry fixed effects, $\hat{\lambda}_{c k}$, obtained from equation (1), (ii) 2008 GDP growth rates, (iii) 2008 import growth rates, and (iv) changes in country credit rating. ${ }^{8}$ The first measure, $\hat{\lambda}_{c k}$, captures each country-industry's overall performance during the crisis. The second and third measures reflect countries' changes in output and demand. The effect of production linkages in enabling MNC subsidiaries to better respond to the crisis should be more pronounced in countries that experienced sharper declines in output and demand. The fourth measure of the incidence, that is, host-country changes in credit rating, helps us examine the financial channel through which FDI affects establishment performance. We expect the effect of financial linkages in reducing establishments' dependence on host-country capital markets and enabling them to achieve sustainability during host-country financial crises to be stronger in countries that experienced greater drops in credit ratings. We follow Rose and Spiegle (2009) in adopting the Euromoney rating that ranks countries on a scale from 0 to 100 with 100 representing the least likelihood of default. Figures 4-6 suggest that our first measure of macroeconomic conditions, directly obtained from estimations, is highly correlated with the other aggregate macro variables and serves as a good indicator of aggregate response to the crisis.

[Figures 4-6 about here]

\footnotetext{
${ }^{8}$ Because the four measures of macroeconomic conditions are negatively associated with the degree of the crisis, we expect a negative relationship between the effect of FDI and each of these measures.
} 
Figures 7-10, which plot the relationship between estimated host-country specific effects of FDI, $\widehat{\beta}_{2 c}$ and the performance of host country economies, reveal a negative and significant relationship for all measures of performance. ${ }^{9}$ As expected from hypothesis 1 , the positive effect of FDI is greater in host countries more adversely affected by the crisis including countries that have experienced slower growth in GDP and imports (for example, Ireland, Italy, Japan, and the U.S.) and countries with a greater drop in credit rating (for example, the U.S., Japan, and Switzerland). In countries such as China, Egypt, and Chile where there was a lesser incidence of the crisis, FDI exerts a less positive or an even negative effect on establishment performance.

[Figures 7-10 about here]

The preceding results are also shown in Table 3 , in which we interact foreign_ $M N C_{i c k}$ with the different measures of macroeconomic conditions, condition $_{c}$, and estimate the following equation:

$$
\begin{aligned}
\text { dSales }_{i c k} & =\alpha+\beta_{1} \text { multi_estab } b_{i c k}+\beta_{2} \text { foreign_} M N C_{i c k}+\beta_{2}^{\prime} \text { foreign_}_{-} M N C_{i c k} \times \text { condition }_{c} \\
& +\beta_{3} \text { domestic_MNC } C_{i c k}+\gamma X_{i c k}+\lambda_{c k}+\varepsilon_{i c k} .
\end{aligned}
$$

As can be seen in Table 3, the estimated parameters of the interaction term $\beta_{2}^{\prime}$ are negative and statistically significant, implying that the effect of FDI decreases with the aggregate performance of host-country economies and increases with the incidence of the crisis.

[Table 3 about here]

\subsubsection{Home-Country Incidence of the Crisis}

Turning to the second part of hypothesis 1, we examine how the role of FDI varies with the incidence of the crisis in home countries by estimating the following equation:

$$
\begin{aligned}
\text { SSales }_{i c k} & =\alpha+\beta_{1} \text { multi_estab }_{i c k}+\beta_{2 h} \text { foreign_MNC } C_{i c k}+\beta_{3} \text { domestic_MNC } C_{i c k} \\
& +\gamma X_{i c k}+\lambda_{c k}+\varepsilon_{i c k}
\end{aligned}
$$

where $\beta_{2 h}$ is the effect of FDI by MNC home country $h$.

[Figures 11-12 about here]

Figures 11-12 plot the relationship between the estimated home-country specific effect of FDI and the performance of home-country economies. As expected from hypothesis 1, MNCs'

\footnotetext{
${ }^{9}$ Only countries with statistically significant estimates (i.e., $\widehat{\beta}_{2 c}$ ) are included in the figures.
} 
performance overseas is positively and significantly correlated with the performance of homecountry economies and negatively correlated with the incidence of the crisis at home. MNCs headquartered in countries in which there has been a lesser incidence of the crisis, reflected in a better overall response to the crisis (such as Australia and China) and a smaller drop in credit ratings (such as Brazil and Turkey), had better performance abroad. Conversely, MNCs headquartered in countries that experienced a greater adverse impact of the crisis, including a greater drop in credit ratings (for example, the U.S., Japan, Spain, and the U.K.), responded to the crisis less satisfactorily abroad and, in some cases, underperformed local firms. We do not, however, find a significant relationship between the foreign performance of MNCs and home-country GDP and import growth rates.

The preceding results are similarly shown in Table 4, in which we interact foreign_ $M N C_{i c k}$ with the macroeconomic variables of home countries, condition ${ }_{h}$, and estimate the following equation:

$$
\begin{aligned}
\text { SSales }_{i c k} & =\alpha+\beta_{1} \text { multi_estab }_{i c k}+\beta_{2} \text { foreign_MNC } C_{i c k}+\beta_{2}^{\prime} \text { foreign_MNC } C_{i c k} \times \text { condition }_{h} \\
& +\beta_{3} \text { domestic_MNC } M C_{i c k}+\gamma X_{i c k}+\lambda_{c k}+\varepsilon_{i c k} .
\end{aligned}
$$

The estimated parameters of the interaction term $\beta_{2}^{\prime}$ are positive and statistically significant in columns (1) and (4), implying that the effect of FDI is positively dependent on the conditions of home-country economies including both the estimated measure of performance and changes in credit ratings. This finding also suggests that during economic crises MNC activities can serve as a linkage that transmits shocks from home to host countries.

In Table 5, we interact foreign_ $M N C_{i c k}$ with the differences of home and host countries in macroeconomic variables, that is, condition $_{h}-$ condition $_{c}$, and find the results to be consistent with the hypothesis. The positive effect of FDI on establishment performance is more pronounced when MNC home countries exhibited better performance in demand and financial conditions relative to host countries.

[Tables 4-5 about here]

\subsection{Production Linkages and Financial Constraints}

Our second hypothesis evaluates the role of production and financial linkages by exploring attributes of MNC activities. We expect multinational establishments that share vertical production linkages with parent firms and engage in activities with stronger financial constraints to exhibit a greater advantage over local firms. This hypothesis is summarized below:

Hypothesis 2 The effect of FDI increases in the vertical production linkages between MNC establishments and parent firms and the financial constraints of establishment activities. 


\subsubsection{Production Linkages}

To test hypothesis 2, we first examine how the role of FDI varies with production linkages between establishments and their foreign parent firms. As described in Section 2.2, we distinguish horizontal and vertical MNC subsidiaries. We interact foreign_ $M N C_{i c k}$ with horizontal $_{i}$ and vertical $_{i}$, respectively, and estimate the following equation:

$$
\begin{aligned}
d \text { Sales }_{i c k} & =\alpha+\beta_{1} \text { multi_estab } b_{i c k}+\beta_{2} \text { foreign_MNC } C_{i c k}+\beta_{2}^{\prime} \text { foreign_}_{-} M N C_{i c k} \times \text { horizontal }_{i} \\
& +\beta_{2}^{\prime \prime} \text { foreign_MNC } C_{i c k} \times \text { vertical }_{i}+\beta_{3} \text { domestic_MNC } M C_{i c k}+\gamma X_{i c k}+\lambda_{c k}+\varepsilon_{i c k} .
\end{aligned}
$$

Table 6 reports the estimates. In the U.S., we do not find a significant difference in the performance of horizontal and vertical subsidiaries; both types exhibited a similar advantage over local establishments. But outside the U.S., horizontal MNC subsidiaries significantly under-performed vertical subsidiaries, suggesting that duplicated cross-country production is more prone to the adverse impact of the crisis relative to the greater resilience exhibited by vertically complementary production. This result is in alignment with the findings of Bernard et al. (2009), who show that intra-firm trade declined less than other types of trade during the Asian Financial crisis.

[Table 6 about here]

Further interacting foreign_ $M N C_{i c k} \times$ horizontal $_{i}$ and foreign_ $M N C_{i c k} \times$ vertical $_{i}$ with estimated host country-industry performance (Table 6, columns (3) and (4)), we find the role of vertical production linkages to be particularly important in host countries that experienced a greater incidence of the crisis. This finding lends further support to the production linkage hypothesis. We also find that both horizontal and production linkages exerted a greater positive effect when home countries exhibited a better response to the crisis.

\subsubsection{Financial constraints}

To investigate the second part of hypothesis 2, that is, how the effect of FDI varies with the financial constraints of establishment activities, we interact foreign_ $M N C_{i c k}$ with financial $_{k}$, the industry specific measure of external finance dependence, and estimate the following equation:

$$
\begin{aligned}
\text { SSales }_{i c k} & =\alpha+\beta_{1} \text { multi_estab }_{i c k}+\beta_{2} \text { foreign_} M N C_{i c k}+\beta_{2}^{\prime} \text { foreign_}_{-} M N C_{i c k} \times \text { financial }_{k} \\
& +\beta_{3} \text { domestic_}_{-} M N C_{i c k}+\gamma X_{i c k}+\lambda_{c k}+\varepsilon_{i c k} .
\end{aligned}
$$

Table 7 reports the estimates. We find the advantage of MNC establishments over local firms to be particularly greater in industries with stronger financial constraints. This is true 
for establishments in the U.S. as well as establishments outside the U.S. Moreover, our results indicate that the advantage of MNC establishments in industries with greater financial constraints decreases in the financial performance of host, and increases in the financial performance of home, countries, emphasizing the importance of financial linkages with parent firms during the crisis.

[Table 7 about here]

\subsection{Multinational Networks}

The third hypothesis of our analysis takes into account the plurilateral nature of many MNCs' international networks. Specifically, we examine whether a larger multinational network amplifies the effect of production and financial linkages, and affects establishment performance during the crisis.

Hypothesis 3 The effect of production and financial linkages increases in the size of multinational networks.

We first construct a variable network $k_{i}$ to measure the number of countries in which establishment $i$ 's ultimate firm owner operates. We then interact this variable with both foreign_MNC $C_{i}$ and domestic_ $M N C_{i}$ and estimate the following equation:

$$
\begin{aligned}
& \text { dSales }_{i c k}=\alpha+\beta_{1} \text { multi_estab }_{i c k}+\beta_{2} \text { foreign_MNC } C_{i c k}+\beta_{2}^{\prime} \text { foreign_}_{-} M N C_{i c k} \times \text { network } \\
& \\
&+\beta_{3} \text { domestic_MNC }_{i c k}+\beta_{3}^{\prime} \text { domestic_MNC } C_{i c k} \times \text { network } k_{i}+\gamma X_{i c k}+\lambda_{c k}+\varepsilon_{i c k} .
\end{aligned}
$$

The parameters of the interaction terms, $\beta_{2}^{\prime}$ and $\beta_{3}^{\prime}$, capture the effect of firm organization size on the performance of individual establishments in host and home countries.

[Table 8 about here]

Table 8 presents the results. We find the effect of multinational networks to differ between the U.S. and other countries. We find no significant relationship between the number of countries in which a multinational operates and the performance of either U.S. based establishments or multinationals headquartered in the U.S. But outside the U.S., establishments of foreign multinationals that owned larger production networks around the world exhibited a significantly greater advantage during the crisis. An increase in the size of network by one country is associated with a 0.6 percentage point improvement in the percentage change of sales. This finding also applies to domestic multinationals, for which an increase in the size of the network by one country corresponds to 0.9 percentage point higher sales growth. 
This result lends support to the positive role of location diversification in times of economic volatility. Operating in more countries offers individual establishments better stability.

The effect of multinational networks also decreases in the performance of host-country economies and increases in the incidence of the crisis (Table 8, columns (3) and (4)). Establishments that were part of larger MNC networks exhibited a particularly greater advantage when host countries experienced a sharper decline in industry performance and credit ratings.

[Table 9 about here]

Table 9 extends the network analysis to further evaluate interdependence within the network. We, first, identify, for each MNC subsidiary, the subset of the MNC network that performs identical production activities. This enables us to separate the effects of horizontal and vertical production linkages. We find that the size of horizontally linked networks, although it does not affect the performance of individual foreign subsidiaries, exerts a negative effect on the performance of home-country establishments, suggesting that home production activities are more prone to the effect of the crisis for MNCs engaged in horizontal foreign investments. When taking into account the average performance of countries within horizontal networks (Table 9, column (4)), we find a negative interdependence between MNC subsidiary performance in a given host country and the performance of countries in which MNCs engage in duplicate production activities. This further confirms the role of horizontal production linkages in increasing the economic volatility of individual establishments.

\section{Sensitivity Analysis}

One potential concern in our analysis is the endogeneity of foreign ownership status. For example, one can argue that foreign MNCs may have performed better, on average, during the crisis because they acquired more productive local firms. If this were the case, the estimated effect of foreign ownership could suffer from a self-selection bias. To address this issue, we employ a matching technique that creates the missing counterfactual of each MNC establishment's response to the crisis had the establishment not been owned by MNCs. This is done by matching each MNC establishment with a local firm based on economic characteristics like sales, age, and exporter status as well as on location and industry factors. Each matched pair thus shared similar economic attributes prior to the crisis, except the status of foreign ownership. We compare the performance of matched establishments at the end of 2008. Different responses to the crisis are attributed to the role of foreign ownership. This approach enables us to control for both observable and unobservable differences between MNC and local establishments in examining the effect of FDI.

We express the goal of estimating the causal effect of FDI as follows:

$$
\beta_{2}=E\left(d_{S a l e s} \mid \text { foreign_MNC }=1\right)-E\left(\text { dSales }_{0} \mid \text { foreign_ } M N C=1\right),
$$


where the subscript of dSales (i.e., 1 and 0) describes the (potentially hypothetical) circumstances (i.e., with or without foreign ownership) under which the outcome (i.e., sales growth) is observed, and ... foreign_ $M N C=1$ refers to the group of establishments that are owned by foreign MNCs (i.e., our treatment group). The foregoing equation represents the difference in sales growth between a foreign owned establishment (the first right-hand-side term) and the same establishment had it not been foreign owned (the second term). The latter, however, is an unobserved counterfactual. The matching method is a strategy of constructing the unobserved counterfactual by identifying a match for each foreign owned establishment that exhibits similar characteristics. The underlying assumption is that the matched pairs, conditioning on the observed characteristics, would perform similarly under the same circumstances. Hence, equation (7) can be rewritten as:

$$
\begin{aligned}
& \beta_{2}=E\left(\text { dSales }_{1} \mid \text { foreign_} M N C=1, \tilde{X}\right)-E\left(\text { dSales }_{0} \mid \text { foreign_} M N C=0, \tilde{X}\right) \\
& -\left[E\left(\text { dSales }_{0} \mid \text { foreign_}_{-} M N C=1, \tilde{X}\right)-E\left(\text { dSales }_{0} \mid \text { foreign_} M N C=0, \tilde{X}\right)\right] .
\end{aligned}
$$

The first difference on the right hand side of the above equation represents the observed difference in sales growth between MNC and local establishments. The second difference represents the selection bias, that is, the difference in sales growth between the MNC establishment, under the hypothetical circumstances that it had not been foreign owned, and local establishments. Our goal is to minimize the selection bias through the matching process and estimate the effect of foreign ownership.

To proceed, we adopt a one-to-one nearest neighbor matching and identify a local firm $l$ for each MNC establishment $i$ such that

$$
l(i)=\underset{j \mid \text { foreign_sub }{ }_{j}=0}{\arg \min }\left|\tilde{X}_{j}-\tilde{X}_{i}\right|
$$

that is, with the minimum difference from MNC establishment $i$ in a vector of economic characteristics $\tilde{X}$ that includes plant-level characteristics prior to the crisis such as sales, age, and exporter status and location and industry fixed effects. To make the analysis feasible, we limit the matching to establishments that are part of multi-unit firms. We evaluate the role of foreign ownership by comparing the sales growth rates of each matched pair, that is, $\beta_{2}=E\left(d\right.$ Sales $\left._{i} \mid \tilde{X}\right)-E\left(\operatorname{dSales}_{l(i)} \mid \tilde{X}\right)$. This yields the estimated effect of foreign ownership on establishment performance during the crisis.

Table 10 reports the estimates. We find the estimated effect of foreign ownership on MNCs' response to the crisis (i.e., average treatment effect on the treated (ATT)) positive and statistically significant. This is true for establishments both within and outside the U.S. In fact, the advantage of foreign MNC establishments is larger in the U.S., equivalent to 72 percentage points higher sales growth rates. MNC establishments in other countries exhibited, 
on average, 19 percentage points higher sales growth compared to their matches.

[Table 10 about here]

\section{Conclusion}

We investigate in this paper the role of foreign direct investment in determining micro economic responses to the global financial crisis. Using a new worldwide dataset that reports operational activities of more than 12 million establishments before and after 2008, we examine patterns of economic crisis at the most disaggregated level. We study how multinationals around the world responded to the crisis relative to local firms, and the underlying mechanisms of those differential responses.

The paper explores three distinct channels through which FDI affects establishment performance, (i) production linkages, (ii) financial linkages, and (iii) multinational networks. The results broadly support all three channels. We find that although multinational owned establishments perform, on average, better than their local competitors, there is considerable heterogeneity in the role of foreign direct investment. The role of foreign direct investment varies significantly with the incidence of the crisis in host and home countries. Multinationals located in host countries that experienced sharper declines in aggregate demand and credit conditions displayed a greater advantage over local firms, and multinationals headquartered in countries with a greater incidence of the crisis, including lower demand and worse credit conditions, fared less satisfactorily overseas. The effect of foreign direct investment also varies with production linkages between foreign establishments and headquarters and extent of financial constraints. Establishments that shared vertical production linkages with parent multinational firms exhibited more resilient performance. Horizontally linked establishments responded less positively. Multinationals that engaged in activities with stronger financial constraints showed a greater advantage over local firms. The size of multinational networks also matters. Being part of a larger multinational network, on average, was associated with superior economic performance during the crisis, but there is a negative interdependence across establishments with horizontal production linkages.

Our results suggest that FDI plays a significant and complex role in micro economic responses to the crisis. It is important to disentangle the underlying channels through which FDI affects establishment performance. FDI can either exacerbate or alleviate the adverse impact of the crisis dependent on the nature of linkages between MNC headquarters and foreign subsidiaries. Our analysis also offers the first micro level evidence of the role of FDI as a potential transmission mechanism during economic crises. Production and financial networks operated by MNCs, both between home and host countries and across different host countries, can serve as an important international linkage in the transmission of economic shocks. These findings are central to academic and policy debates centered on the role of 
foreign direct investment in economic growth, volatility, and cross-country economic interdependence, and have critical implications for policy making aimed at influencing the flow of foreign investments.

\section{References}

[1] Acemoglu, Daron, Simon Johnson, and Todd Mitton (2009) Determinants of Vertical Integration: Financial Development and Contracting Costs. Journal of Finance 63, 12511290.

[2] Alfaro, Laura and Andrew Charlton (2009) Intra-Industry Foreign Direct Investment. American Economic Review 99 (5), 2096-2119.

[3] Alfaro, Laura, Areendam Chanda, Sebnem Kalemli-Ozcan, and Selin Sayek (2004) FDI and Economic Growth: the Role of Local Financial Markets. Journal of International Economics 64 (1), 89-112.

[4] Alfaro, Laura, Sebnem Kalemli-Ozcan, and Selin Sayek (2009) Foreign Direct Investment, Productivity and Financial Development: An Empirical Analysis of Complementarities and Channels. World Economy 32, 111-135.

[5] Alvarez, Roberto and Holger Görg (2007) Multinationals as Stabilizers? Economic Crisis and Plant Employment Growth. IZA Discussion Paper 2692.

[6] Baldwin, Richard and Simon Evenett (2009) The Collapse of Global Trade, Murky Protectionism, and the Crisis: Recommendations for the G20. A VoxEU.org Publication.

[7] Bems Rudolfs, Robert Johnson, and Kei-Mu Yi (2010) Demand Spillovers and the Collapse of Trade in the Global Recession. Mimeo.

[8] Bernard, Andrew and Bradford Jensen (2007) Firm Structure, Multinationals and Manufacturing Plant Deaths. Review of Economics and Statistics 89 (2), 193-204.

[9] Bernard, Andrew and Fredrik Sjoholm (2003) Foreign Owners and Plant Survival. NBER Working Paper No. 10039.

[10] Bernard, Andrew, Bradford Jensen, Stephen Redding, and Peter Schott (2009) The Margins of US Trade. American Economic Review Papers and Proceedings 99 (2), 487-493.

[11] Berkman, Pelin, Gaston Gelos, Robert Rennhack, and James Walsh (2010) The Global Financial Crisis: Explaining Cross-Country Differences in the Output Impact. IMF Working Paper WP/09/280. 
[12] Black, S. E., and P. E. Strahan (2002) Entrepreneurship and Bank Credit Availability. Journal of Finance 57, 2807-2833.

[13] Braun, M. (2003) Financial Contractibility and Asset Hardness. University of California at Los Angeles. Mimeo.

[14] Borensztein, E., J. De Gregorio, and J-W. Lee (1998) How Does Foreign Direct Investment Affect Economic Growth? Journal of International Economics 45, 115-135.

[15] Bricongne, Jean-Charles, Lionel Fontagné, Guillaume Gaulier, Daria Taglioni and Vincent Vicard. (2009). Firms and the Global crisis: French exports in the turmoil. Mimeo.

[16] Carkovic, M. and R. Levine (2005) Does Foreign Direct Investment Accelerate Economic Growth? In T. Moran, E. Grahan, and M. Blomström (eds.), Does Foreign Direct Investment Promote Development? Washington D.C.: Institute for International Economics.

[17] Caves, Richard E. (1975) Diversification, Foreign Investment and Scale in North American Manufacturing Industries. Ottawa: Economic Council of Canada.

[18] Chor, Davin and Kalina Manova (2009) Off the Cliff and Back: Credit Conditions and International Trade during the Global Financial Crisis. Mimeo.

[19] Desai, Mihir, Fritz Foley, and Kristin J. Forbes (2008) Financial Constraints and Growth: Multinational and Local Firm Responses to Currency Depreciations. Review of Financial Studies 21 (6), 2857-2888.

[20] Eaton, Jonathan, Sam Kortum, Brent Neiman, and John Romalis (2009). Trade and the Global Recession. Mimeo.

[21] Eichengreen, B., A. Rose, C. Wyplosz (1996) Contagious Currency Crises. NBER Working Paper No. 5681, Cambridge, MA.

[22] Forbes, Kristin (2004) The Asian Flu and Russian Virus: The International Transmission of Crises in Firm-Level Data. Journal of International Economics 63(1), 59-92.

[23] Gibson, John and Richard I. D. Harris (1996) Trade Liberalization and Plant Exit in New Zealand Manufacturing. Review of Economics and Statistics 78 (3), 521-529.

[24] Glick, R. and A. Rose (1999) Contagion and Trade: Why are Currency Crises Regional? Journal of International Money and Finance 18, 603-617.

[25] Görg, Holger and Eric Strobl (2003) Footloose Multinationals? The Manchester School $71,1-19$. 
[26] Harrison, A. E., I. Love, and M. S. McMillian (2004) Global Capital Flows and Financing Constraints. Journal of Development Economics 75, 269-301.

[27] Helpman, Elhanan, Marc Melitz, and Stephen Yeaple (2004) Export versus FDI with Heterogeneous Firms. American Economic Review 94 (1), 300-316.

[28] Lipsey, Robert E. (1978) The Creation of Microdata Sets for Enterprises and Establishments. Annales de l'INSEE 30-31, 395-422.

[29] Kaminsky, G., R. Lyons, and S. Schmukler (2001) Mutual Fund Investment in Emerging Markets: An Overview. In: Claessens, S., Forbes, K. (Eds.), International Financial Contagion. Kluwer Academic Publishers, Boston, 158-185.

[30] Rose, Andrew and Mark Spiegel (2009) The Causes and Consequences of the 2008 Crisis: International Linkages and American Exposure. Pacific Economic Review, forthcoming.

[31] Tong, Hui and Shang-Jin Wei (2009) The Composition Matters: Capital Inflows and Liquidity Crunch during a Global Economic Crisis. NBER Working Paper No. 15207.

[32] UNCTAD (2009) World Investment Report: Transnational Corporations, Agricultural Production and Development. 

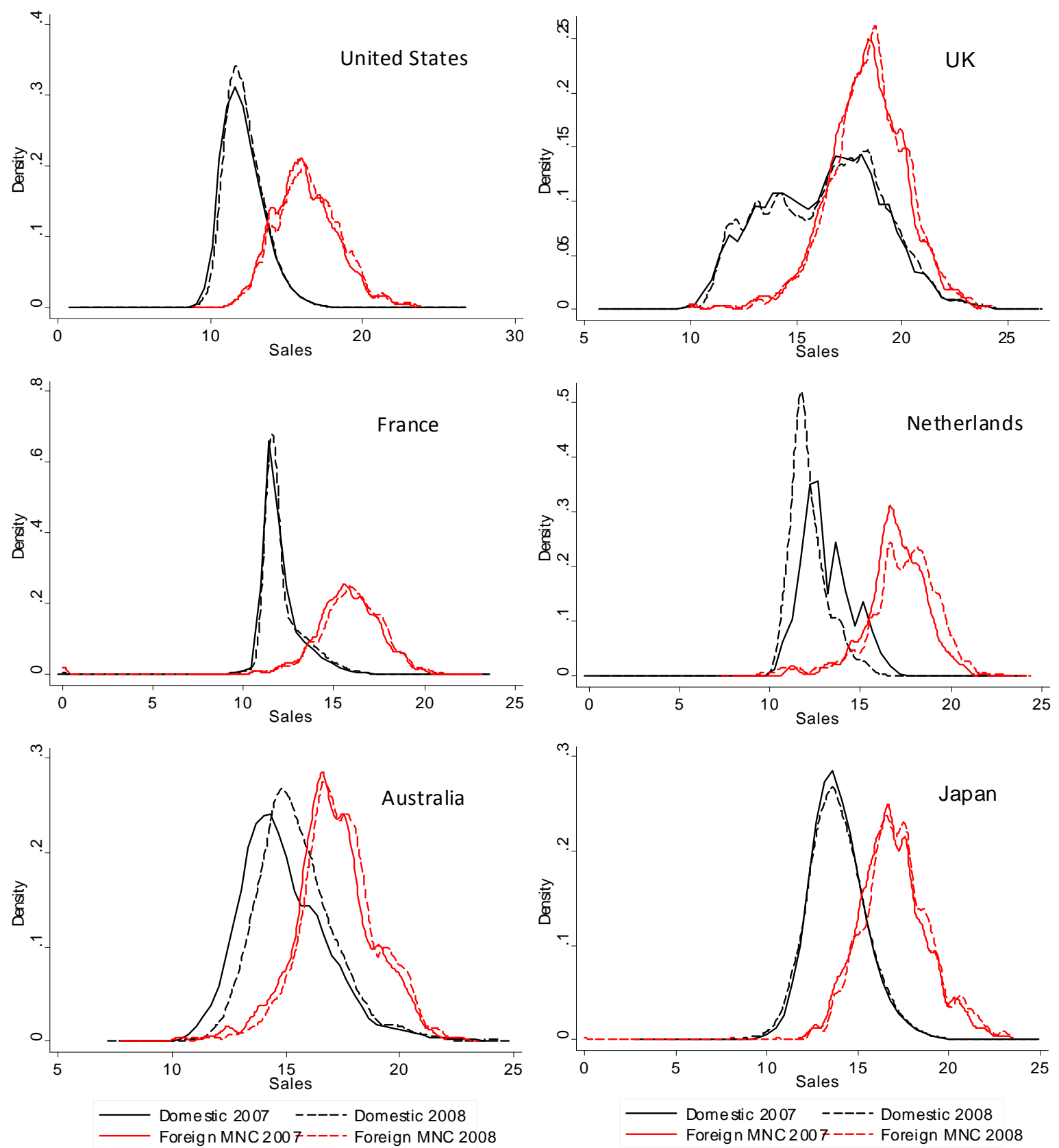

Figure 1: Distribution of domestic and multinational establishments: developed countries 

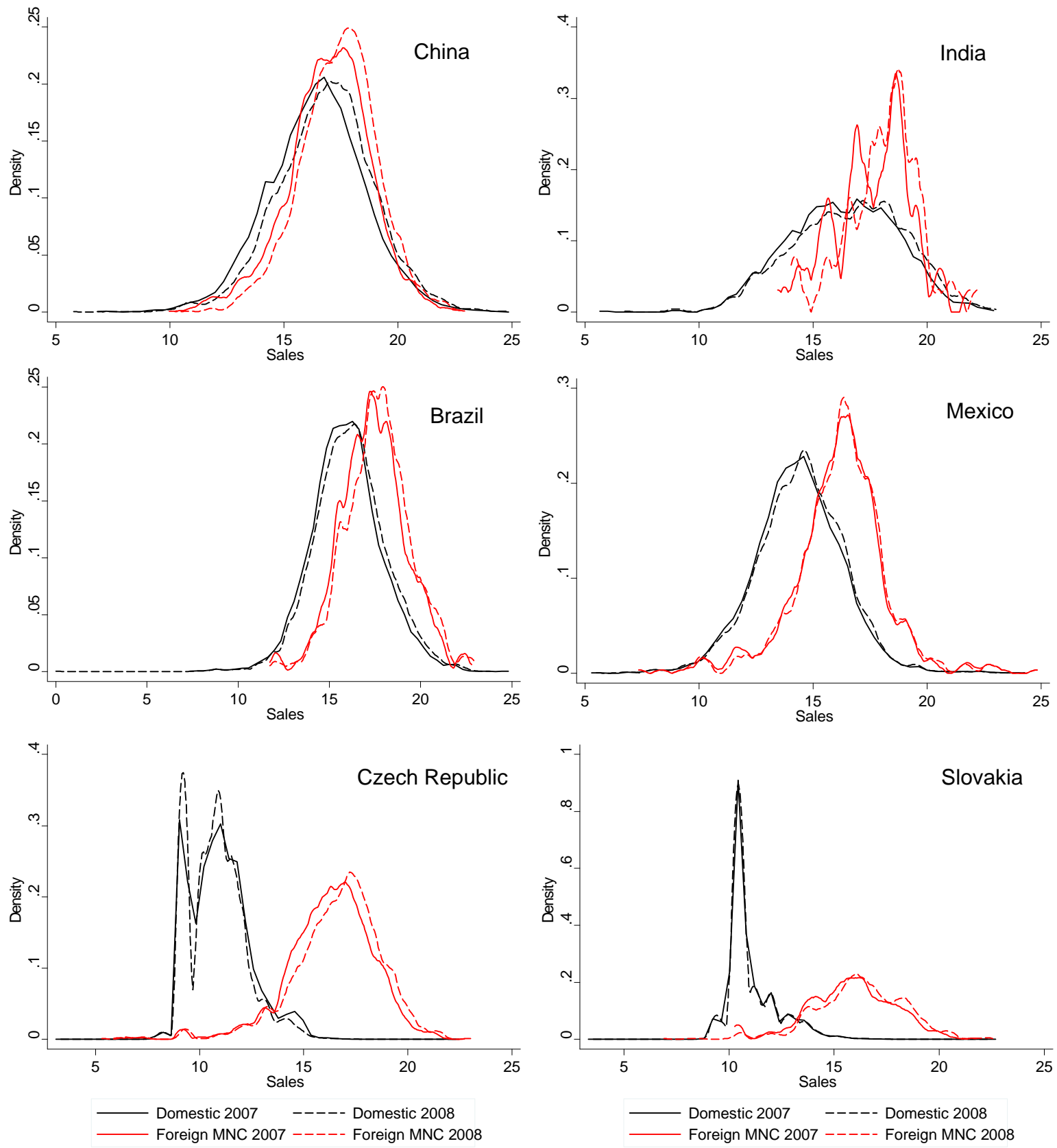

Figure 2: Distribution of domestic and multinational establishments: developing countries 

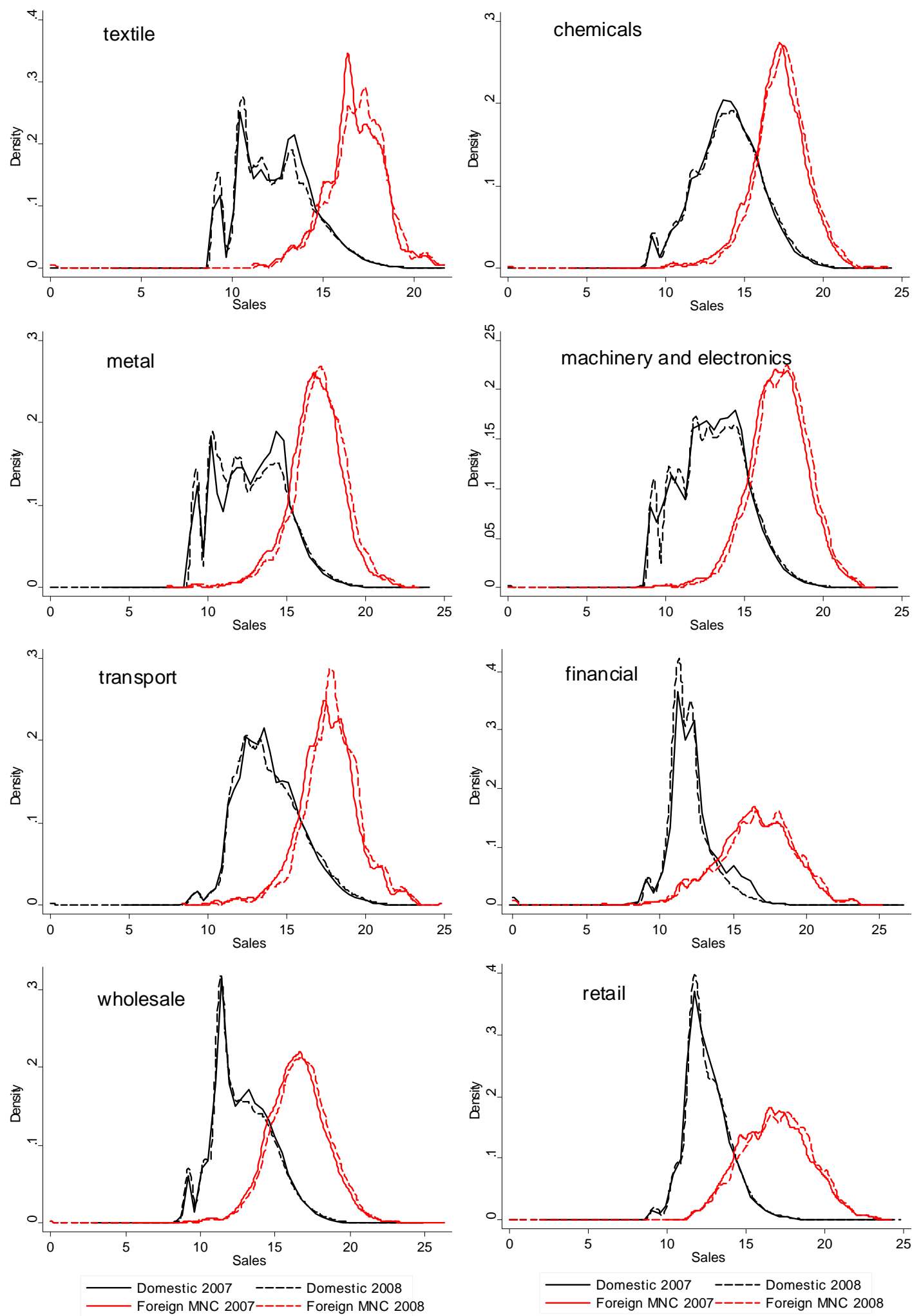

Figure 3: Distribution of domestic and multinational establishments across industries 


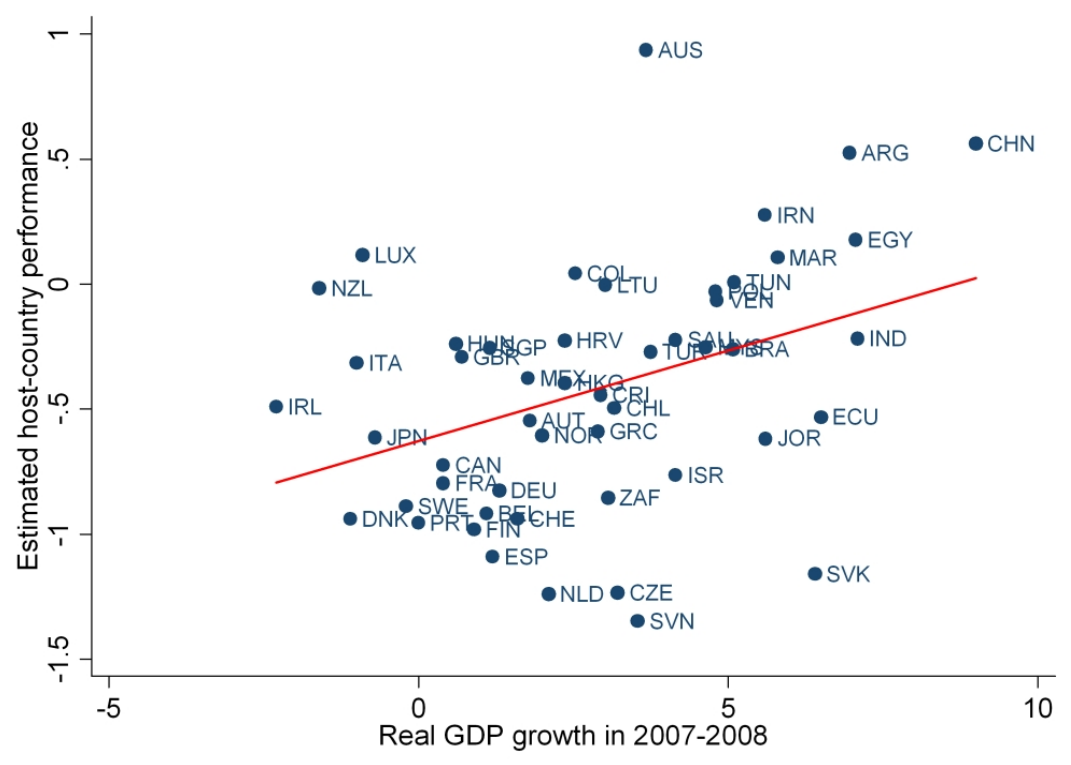

Figure 4: Estimated host-country response to the crisis and real GDP growth rate

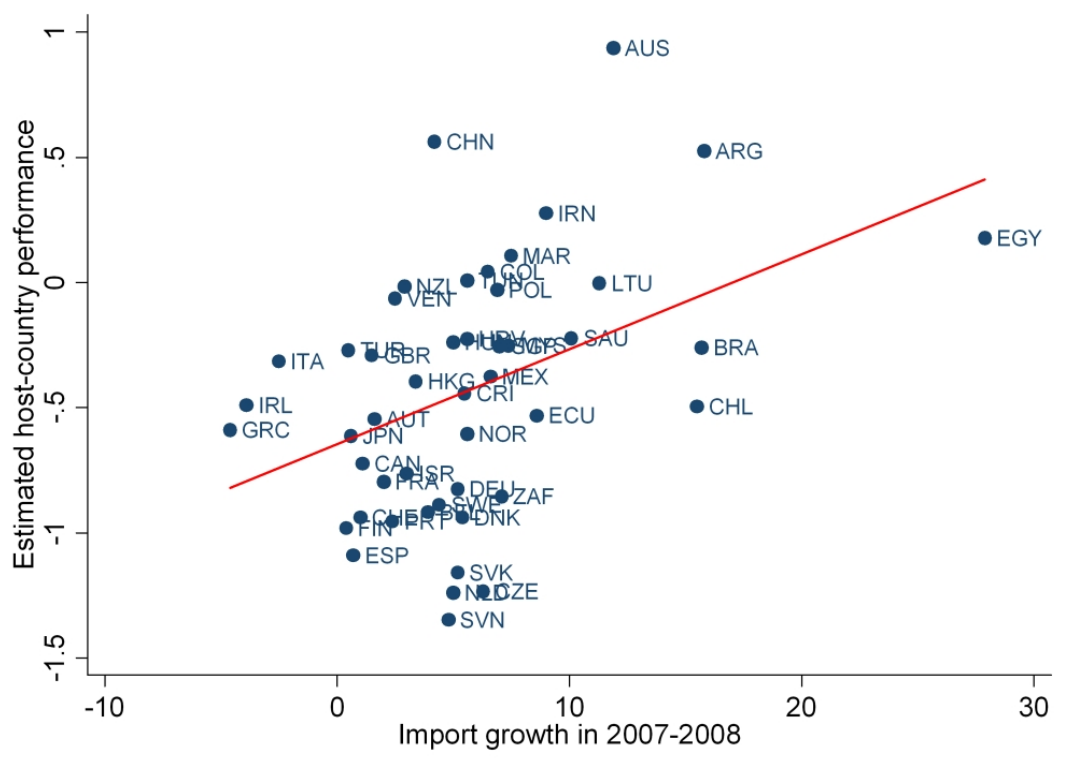

Figure 5: Estimated host-country response to the crisis and import growth rate 


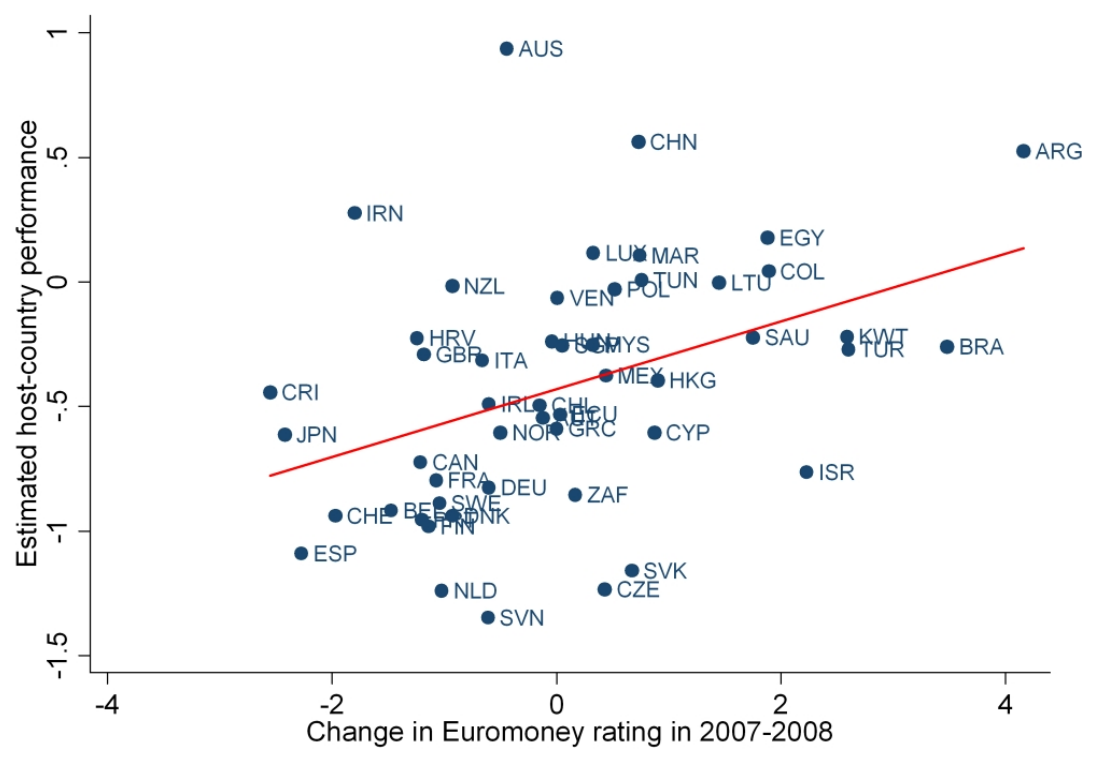

Figure 6: Estimated host-country response to the crisis and change in credit rating

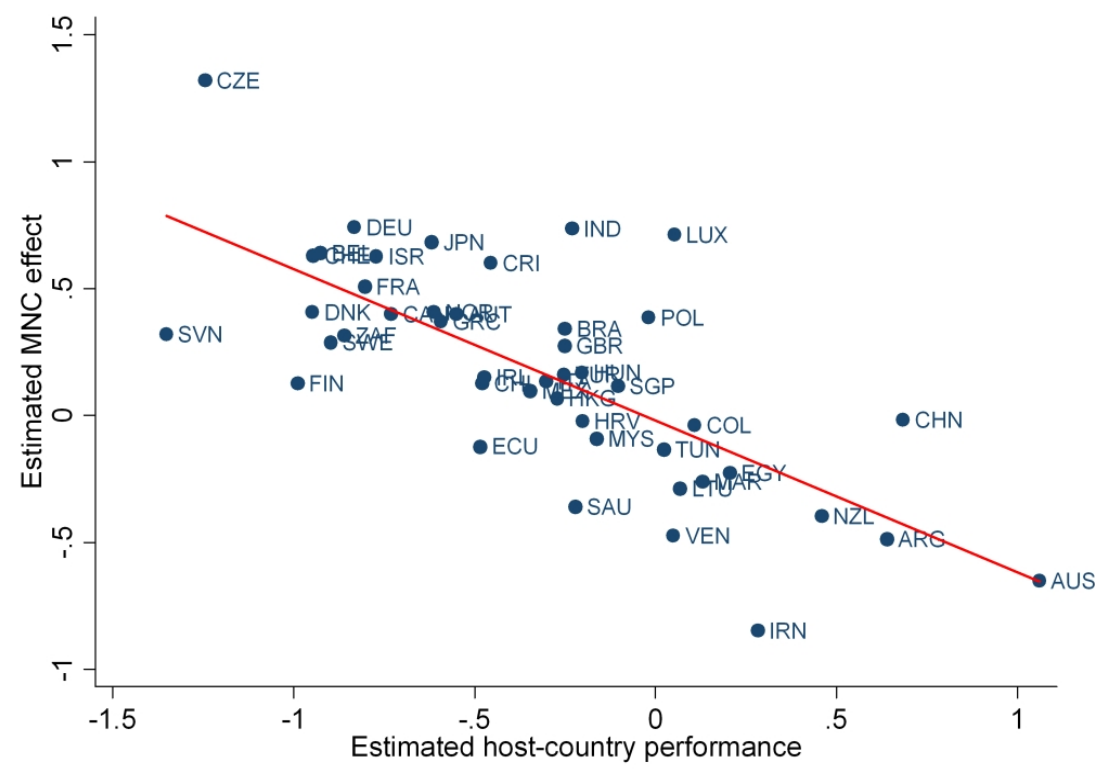

Figure 7: Effect of foreign ownership and estimated host-country response to the crisis 


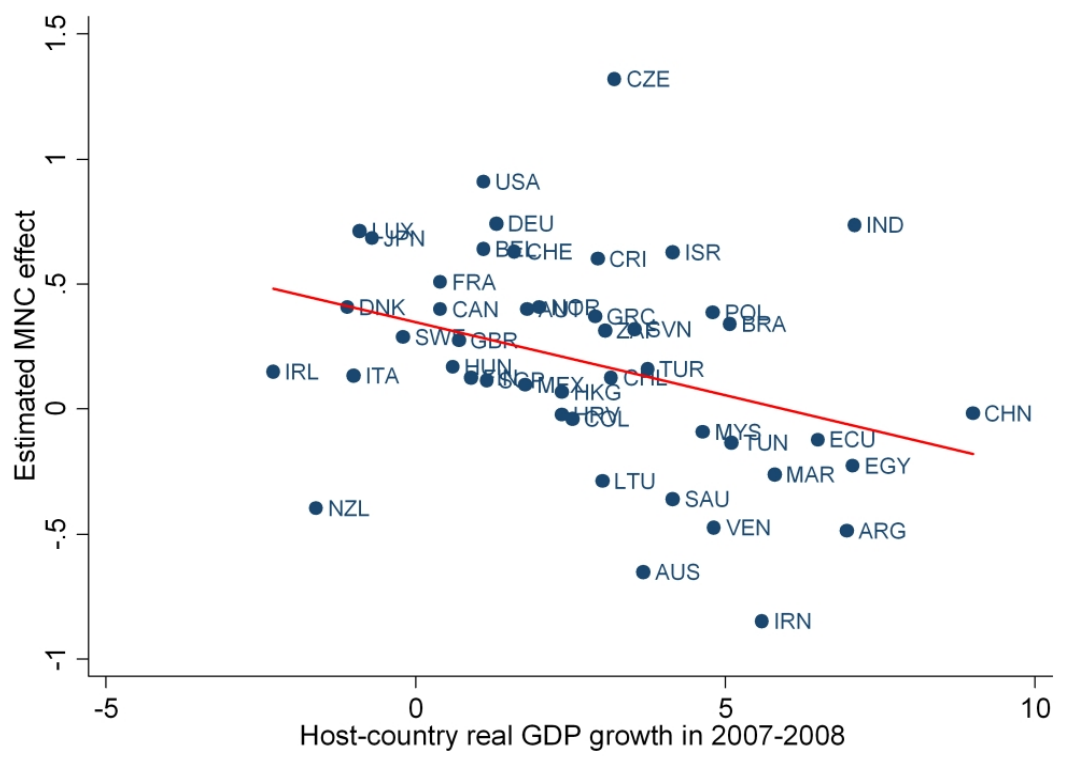

Figure 8: Effect of foreign ownership and host-country real GDP growth

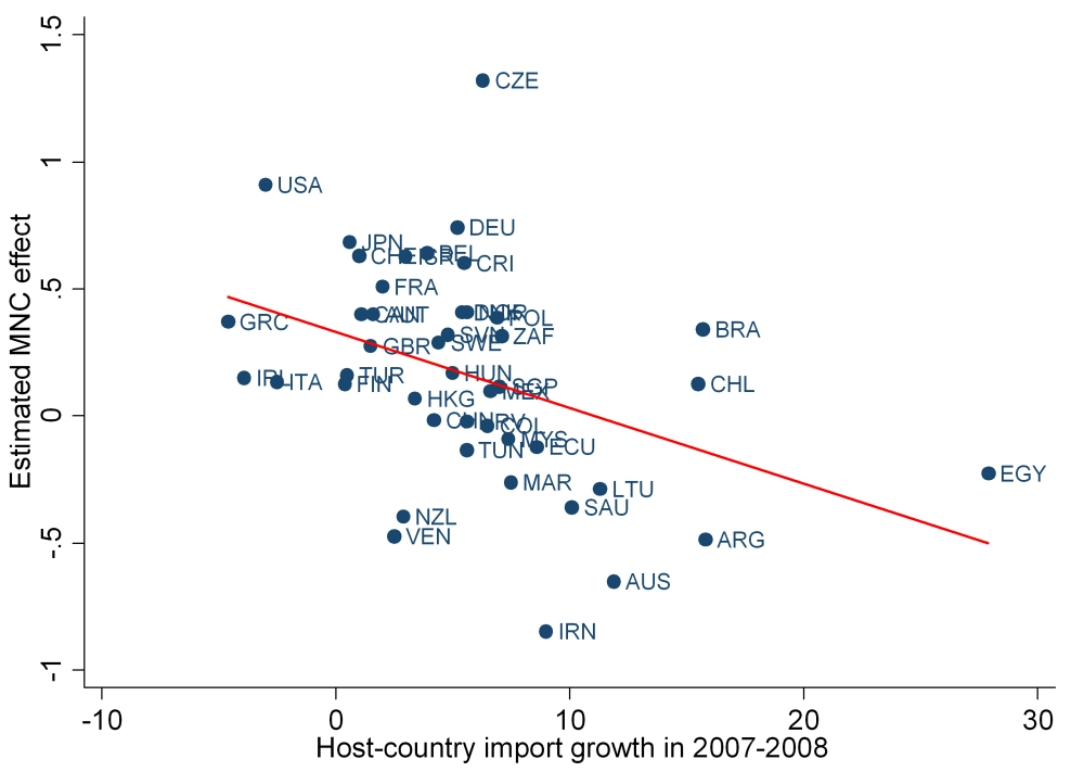

Figure 9: Effect of foreign ownership and host-country import growth 


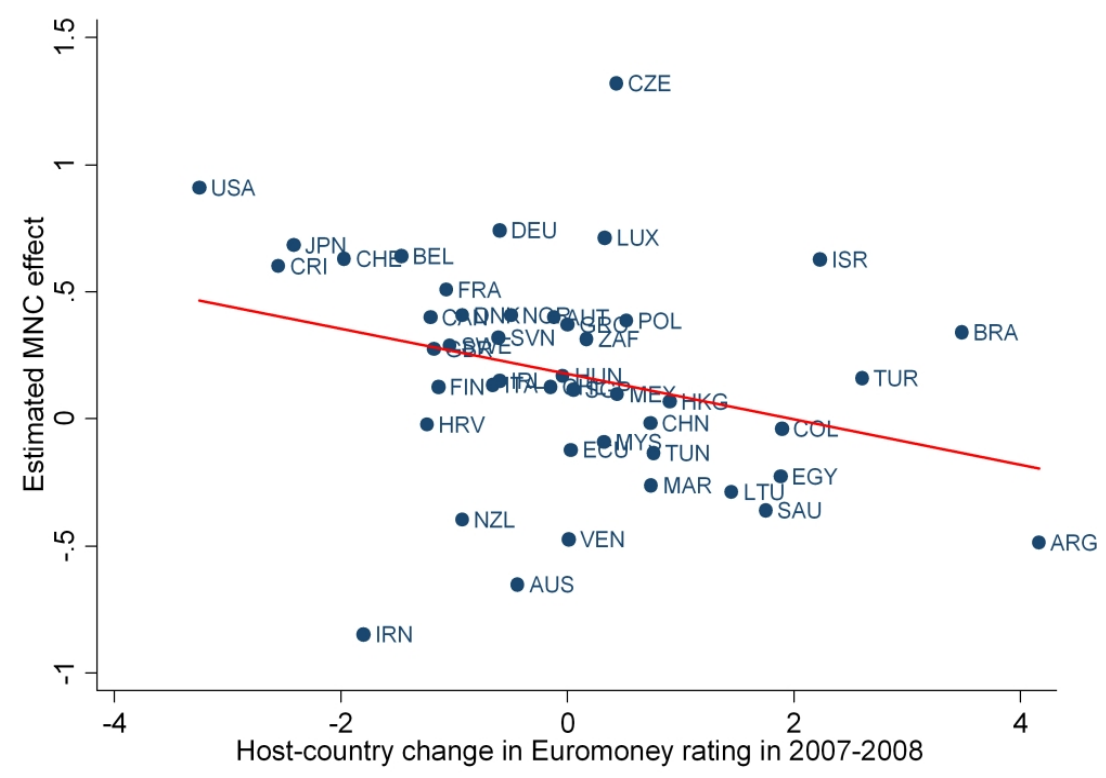

Figure 10: Effect of foreign ownership and host-country change in credit rating

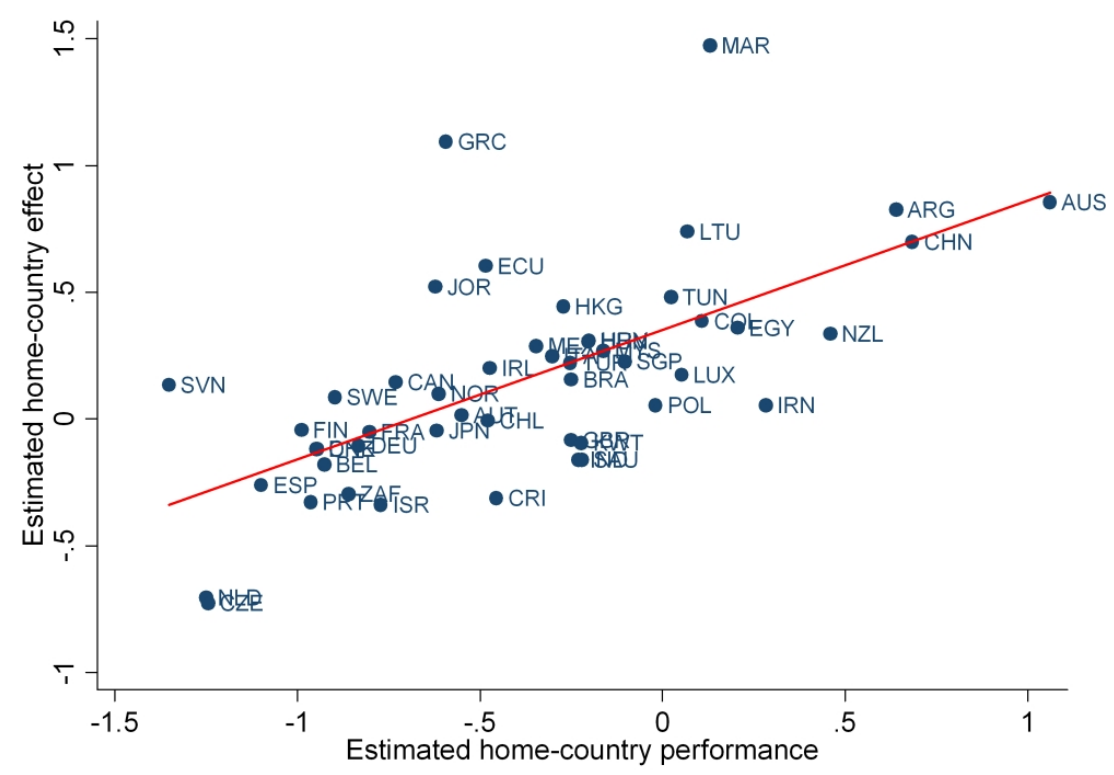

Figure 11: Effect of country ownership and estimated home-country response to the crisis 


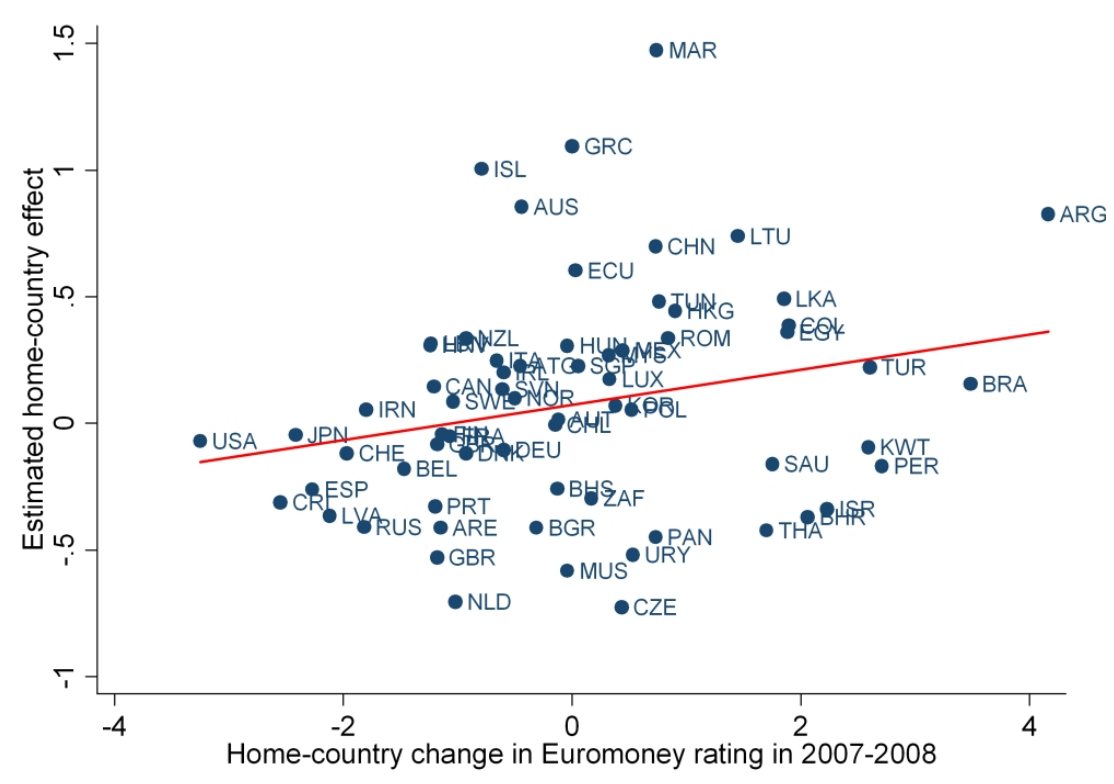

Figure 12: Effect of country ownership and home-country change in credit rating 
Table 1: The role of FDI: baseline evidence (U.S.)

(Dependent variable: Percentage change of sales)

\begin{tabular}{|c|c|c|c|c|c|}
\hline & (1) & (2) & (3) & (4) & (5) \\
\hline \multicolumn{6}{|l|}{ Ownership } \\
\hline Multi-establishment & $\begin{array}{c}0.115^{* * *} \\
(0.022)\end{array}$ & $\begin{array}{c}0.088^{* * *} \\
(0.020)\end{array}$ & $\begin{array}{c}0.079^{* * *} \\
(0.020)\end{array}$ & $\begin{array}{c}0.237^{* * *} \\
(0.020)\end{array}$ & $\begin{array}{c}0.232^{* * *} \\
(0.019)\end{array}$ \\
\hline Foreign MNC & & $\begin{array}{c}0.873^{* * *} \\
(0.100)\end{array}$ & $\begin{array}{c}0.884^{* * *} \\
(0.100)\end{array}$ & $\begin{array}{c}0.941^{* * *} \\
(0.104)\end{array}$ & $\begin{array}{c}0.922^{* * *} \\
(0.103)\end{array}$ \\
\hline Domestic MNC & & & $\begin{array}{c}0.258^{* * *} \\
(0.047)\end{array}$ & $\begin{array}{c}0.432^{* * *} \\
(0.049)\end{array}$ & $\begin{array}{c}0.421^{* * *} \\
(0.050)\end{array}$ \\
\hline \multicolumn{6}{|c|}{ Economic characteristics } \\
\hline Sales & & & & $\begin{array}{c}-0.067^{* * *} \\
(0.004)\end{array}$ & $\begin{array}{c}-0.067^{* * *} \\
(0.004)\end{array}$ \\
\hline Age & & & & $\begin{array}{c}0.031^{* * *} \\
(0.005)\end{array}$ & $\begin{array}{c}0.031^{* * *} \\
(0.005)\end{array}$ \\
\hline Multiproduct & & & & $\begin{array}{c}0.051^{* * *} \\
(0.004)\end{array}$ & $\begin{array}{c}0.051^{* * *} \\
(0.004)\end{array}$ \\
\hline Exporter & & & & & $\begin{array}{c}0.221^{* * *} \\
(0.073)\end{array}$ \\
\hline Industry FE & yes & yes & yes & yes & yes \\
\hline Industry cluster & yes & yes & yes & yes & yes \\
\hline Obs. & $5,364,640$ & $5,364,640$ & $5,364,640$ & $5,364,640$ & $5,364,640$ \\
\hline $\mathrm{R}$ square & 0.02 & 0.02 & 0.03 & 0.04 & 0.04 \\
\hline $\mathrm{R}$ square & 0.03 & 0.03 & 0.03 & 0.03 & 0.03 \\
\hline Root MSE & 0.87 & 0.87 & 0.87 & 0.87 & 0.87 \\
\hline
\end{tabular}

Notes: OLS estimates reported. Clustered standard errors in parentheses, ${ }^{* * *} \mathrm{p}<0.01,{ }^{* *} \mathrm{p}<0.05,{ }^{*}$ $\mathrm{p}<0.1$. All regressions include industry fixed effect. See text for detailed descriptions of the variables. 
Table 2: The role of FDI: baseline evidence (non-U.S. countries) (Dependent variable: Percentage change of sales)

\begin{tabular}{|c|c|c|c|c|c|}
\hline & (1) & (2) & (3) & (4) & (5) \\
\hline \multicolumn{6}{|l|}{ Ownership } \\
\hline Multi-establishment & $\begin{array}{c}0.067^{* * *} \\
(0.007)\end{array}$ & $\begin{array}{c}0.068^{* * *} \\
(0.008)\end{array}$ & $\begin{array}{c}0.064^{* * *} \\
(0.008)\end{array}$ & $\begin{array}{c}0.343^{* * *} \\
(0.013)\end{array}$ & $\begin{array}{c}0.342^{* * *} \\
(0.013)\end{array}$ \\
\hline Foreign MNC & & $\begin{array}{c}0.067^{* * *} \\
(0.024)\end{array}$ & $\begin{array}{c}0.073^{* * *} \\
(0.025)\end{array}$ & $\begin{array}{c}0.251^{* * *} \\
(0.026)\end{array}$ & $\begin{array}{c}0.237^{* * *} \\
(0.026)\end{array}$ \\
\hline Domestic MNC & & & $\begin{array}{c}0.086^{* * *} \\
(0.027)\end{array}$ & $\begin{array}{c}0.358^{* * *} \\
(0.029)\end{array}$ & $\begin{array}{c}0.347^{* * *} \\
(0.029)\end{array}$ \\
\hline \multicolumn{6}{|l|}{ Economic characteristics } \\
\hline Sales & & & & $\begin{array}{c}-0.164^{* * *} \\
(0.007)\end{array}$ & $\begin{array}{c}-0.165^{* * *} \\
(0.007)\end{array}$ \\
\hline Age & & & & $\begin{array}{c}-0.133^{* * *} \\
(0.012)\end{array}$ & $\begin{array}{c}-0.134^{* * *} \\
(0.012)\end{array}$ \\
\hline Multiproduct & & & & $\begin{array}{c}0.078^{* * *} \\
(0.007)\end{array}$ & $\begin{array}{c}0.077^{* * *} \\
(0.007)\end{array}$ \\
\hline Exporter & & & & & $\begin{array}{c}0.131^{* * *} \\
(0.010)\end{array}$ \\
\hline Country-industry FE & yes & yes & yes & yes & yes \\
\hline Country-industry cluster & yes & yes & yes & yes & yes \\
\hline Obs. & $6,852,326$ & $6,852,326$ & $6,852,326$ & $6,852,326$ & $6,852,326$ \\
\hline $\mathrm{R}$ square & 0.05 & 0.05 & 0.05 & 0.07 & 0.07 \\
\hline Root MSE & 1.48 & 1.48 & 1.48 & 1.47 & 1.47 \\
\hline
\end{tabular}

Notes: OLS estimates reported. Clustered standard errors in parentheses, ${ }^{* * *} \mathrm{p}<0.01,{ }^{* *} \mathrm{p}<0.05,{ }^{*}$ $\mathrm{p}<0.1$. All regressions include country-industry fixed effect. See text for detailed descriptions of the variables. 
Table 3: The role of FDI: host-country incidence of the crisis (Dependent variable: Percentage change of sales)

\begin{tabular}{|c|c|c|c|c|}
\hline & $(1)$ & $(2)$ & $(3)$ & $(4)$ \\
\hline \multicolumn{5}{|l|}{ Ownership } \\
\hline Multi-establishment & $\begin{array}{c}0.341^{* * *} \\
(0.013)\end{array}$ & $\begin{array}{c}0.342^{* * *} \\
(0.013)\end{array}$ & $\begin{array}{c}0.342^{* * *} \\
(0.013)\end{array}$ & $\begin{array}{c}0.342^{* * *} \\
(0.013)\end{array}$ \\
\hline Foreign MNC & $\begin{array}{c}0.471^{* * *} \\
(0.050)\end{array}$ & $\begin{array}{c}0.254^{* * *} \\
(0.029)\end{array}$ & $\begin{array}{c}0.299^{* * *} \\
(0.031)\end{array}$ & $\begin{array}{c}0.210^{* * *} \\
(0.028)\end{array}$ \\
\hline x Estimated host-industry performance & $\begin{array}{c}-0.414^{* * *} \\
(0.087)\end{array}$ & & & \\
\hline x Host-country GDP growth & & $\begin{array}{c}-0.058^{* * *} \\
(0.024)\end{array}$ & & \\
\hline x Host-country import growth & & & $\begin{array}{c}-0.015^{* * *} \\
(0.006)\end{array}$ & \\
\hline $\mathrm{x}$ Host-country change in credit rating & & & & $\begin{array}{c}-0.069^{* * *} * \\
(0.018)\end{array}$ \\
\hline Domestic MNC & $\begin{array}{c}0.346^{* * *} \\
(0.029)\end{array}$ & $\begin{array}{c}0.349^{* * *} \\
(0.029)\end{array}$ & $\begin{array}{c}0.349^{* * *} \\
(0.029)\end{array}$ & $\begin{array}{c}0.349^{* * *} \\
(0.029)\end{array}$ \\
\hline \multicolumn{5}{|l|}{ Economic characteristics } \\
\hline Sales & $\begin{array}{c}-0.165^{* * *} \\
(0.007)\end{array}$ & $\begin{array}{c}-0.165^{* * *} \\
(0.007)\end{array}$ & $\begin{array}{c}-0.165^{* * *} \\
(0.007)\end{array}$ & $\begin{array}{c}-0.165^{* * *} \\
(0.007)\end{array}$ \\
\hline Age & $\begin{array}{c}-0.134^{* * *} \\
(0.012)\end{array}$ & $\begin{array}{c}-0.134^{* * *} \\
(0.012)\end{array}$ & $\begin{array}{c}-0.134^{* * *} \\
(0.012)\end{array}$ & $\begin{array}{c}-0.134^{* * *} \\
(0.012)\end{array}$ \\
\hline Multiproduct & $\begin{array}{c}0.077^{* * *} \\
(0.007)\end{array}$ & $\begin{array}{c}0.077^{* * *} \\
(0.007)\end{array}$ & $\begin{array}{c}0.077^{* * *} \\
(0.007)\end{array}$ & $\begin{array}{c}0.077^{* * *} \\
(0.007)\end{array}$ \\
\hline Exporter & $\begin{array}{c}0.130^{* * *} \\
(0.010)\end{array}$ & $\begin{array}{c}0.131^{* * *} \\
(0.010)\end{array}$ & $\begin{array}{c}0.131^{* * *} \\
(0.010)\end{array}$ & $\begin{array}{c}0.131^{* * *} \\
(0.010)\end{array}$ \\
\hline Country-industry FE & yes & yes & yes & yes \\
\hline Country-industry cluster & yes & yes & yes & yes \\
\hline Obs. & $6,852,326$ & $6,852,326$ & $6,852,326$ & $6,852,326$ \\
\hline $\mathrm{R}$ square & 0.07 & 0.07 & 0.07 & 0.07 \\
\hline Root MSE & 1.47 & 1.47 & 1.47 & 1.47 \\
\hline
\end{tabular}

Notes: OLS estimates reported. Clustered standard errors in parentheses, ${ }^{* * *} \mathrm{p}<0.01,{ }^{* *} \mathrm{p}<0.05$, ${ }^{*}$ $\mathrm{p}<0.1$. All regressions include country-industry fixed effect. See text for detailed descriptions of the variables. 
Table 4: The role of FDI: home-country incidence of the crisis

(Dependent variable: Percentage change of sales)

\begin{tabular}{lcccc}
\hline \hline & $(1)$ & $(2)$ & $(3)$ & $(4)$ \\
\hline Ownership & & & & \\
Multi-establishment & $0.340^{* * *}$ & $0.342^{* * *}$ & $0.341^{* * *}$ & $0.341^{* * *}$ \\
& $(0.013)$ & $(0.013)$ & $(0.013)$ & $(0.013)$ \\
Foreign MNC & $0.317^{* * *}$ & $0.224^{* * *}$ & $0.237^{* * *}$ & $0.274^{* * *}$ \\
& $(0.039)$ & $(0.034)$ & $(0.028)$ & $(0.032)$ \\
x Estimated MNC home-industry performance & $0.236^{* * *}$ & & & \\
& $(0.085)$ & & & \\
x MNC home-country GDP growth & & 0.013 & & \\
& & $(0.021)$ & & \\
x MNC home-country import growth & & & -0.003 & \\
& & & & \\
x MNC home-country change in credit rating & & & & $0.005)$ \\
& & & & \\
Domestic MNC & $0.345^{* * *}$ & $0.349^{* * *}$ & $0.349^{* * *}$ & $0.348^{* * *}$ \\
& $(0.029)$ & $(0.029)$ & $(0.029)$ & $(0.029)$ \\
Economic characteristics & & & & \\
Sales & $-0.165^{* * *}$ & $-0.165^{* * *}$ & $-0.165^{* * *}$ & $-0.165^{* * *}$ \\
& $(0.007)$ & $(0.007)$ & $(0.007)$ & $(0.007)$ \\
Age & $-0.133^{* * *}$ & $-0.134^{* * *}$ & $-0.134^{* * *}$ & $-0.134^{* * *}$ \\
Multiproduct & $(0.012)$ & $(0.012)$ & $(0.012)$ & $(0.012)$ \\
Exporter & $0.076^{* * *}$ & $0.077^{* * *}$ & $0.077^{* * *}$ & $0.077^{* * *}$ \\
Country-industry FE & $(0.007)$ & $(0.007)$ & $(0.007)$ & $(0.007)$ \\
Country-industry cluster & $0.133^{* * *}$ & $0.131^{* * *}$ & $0.131^{* * *}$ & $0.131^{* * *}$ \\
Obs. & $(0.010)$ & $(0.010)$ & $(0.010)$ & $(0.010)$ \\
R square & yes & yes & yes & yes \\
Root MSE & yes & yes & yes & yes \\
\hline \hline & $6,852,326$ & $6,852,326$ & $6,852,326$ & $6,852,326$ \\
& 0.07 & 0.07 & 0.07 & 0.07 \\
& 1.47 & 1.47 & 1.47 & 1.47 \\
\hline
\end{tabular}

Notes: OLS estimates reported. Clustered standard errors in parentheses, ${ }^{* * *} \mathrm{p}<0.01,{ }^{* *} \mathrm{p}<0.05,{ }^{*}$ $\mathrm{p}<0.1$. All regressions include country-industry fixed effect. See text for detailed descriptions of the variables. 
Table 5: The role of FDI: country difference in crisis incidence

(Dependent variable: Percentage change of sales)

\begin{tabular}{|c|c|c|c|c|}
\hline & (1) & 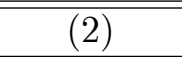 & (3) & 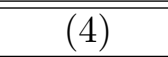 \\
\hline \multicolumn{5}{|l|}{ Ownership } \\
\hline Multi-establishment & $\begin{array}{c}0.340^{* * *} \\
(0.013)\end{array}$ & $\begin{array}{c}0.342^{* * *} \\
(0.013)\end{array}$ & $\begin{array}{c}0.341^{* * *} \\
(0.013)\end{array}$ & $\begin{array}{c}0.342^{* * *} \\
(0.013)\end{array}$ \\
\hline Foreign MNC & $\begin{array}{c}0.317^{* * * *} \\
(0.039)\end{array}$ & $\begin{array}{c}0.243^{* * *} \\
(0.025)\end{array}$ & $\begin{array}{c}0.249^{* * *} \\
(0.025)\end{array}$ & $\begin{array}{c}0.285^{* * *} \\
(0.028)\end{array}$ \\
\hline $\mathrm{x}$ MNC home-host diff. in estimated performance & $\begin{array}{c}0.236^{* * *} \\
(0.085)\end{array}$ & & & \\
\hline $\mathrm{x}$ MNC home-host diff. in GDP growth & & $\begin{array}{c}0.005 \\
(0.009)\end{array}$ & & \\
\hline $\mathrm{x}$ MNC home-host diff. in import growth & & & $\begin{array}{l}0.007^{*} \\
(0.004)\end{array}$ & \\
\hline $\mathrm{x}$ MNC home-host diff. in credit rating changes & & & & $\begin{array}{c}0.039^{* * *} \\
(0.009)\end{array}$ \\
\hline Domestic MNC & $\begin{array}{c}0.345^{* * *} \\
(0.029)\end{array}$ & $\begin{array}{c}0.347^{* * *} \\
(0.029)\end{array}$ & $\begin{array}{c}0.347^{* * *} \\
(0.029)\end{array}$ & $\begin{array}{c}0.347^{* * *} \\
(0.029)\end{array}$ \\
\hline \multicolumn{5}{|l|}{ Economic characteristics } \\
\hline Sales & $\begin{array}{c}-0.165^{* * *} \\
(0.007)\end{array}$ & $\begin{array}{c}-0.165^{* * *} \\
(0.007)\end{array}$ & $\begin{array}{c}-0.165^{* * *} \\
(0.007)\end{array}$ & $\begin{array}{c}-0.165^{* * *} \\
(0.007)\end{array}$ \\
\hline Age & $\begin{array}{c}-0.133^{* * *} \\
(0.012)\end{array}$ & $\begin{array}{c}-0.134^{* * *} \\
(0.012)\end{array}$ & $\begin{array}{c}-0.134^{* * *} \\
(0.012)\end{array}$ & $\begin{array}{c}-0.134^{* * *} \\
(0.012)\end{array}$ \\
\hline Multiproduct & $\begin{array}{c}0.076^{* * *} \\
(0.007)\end{array}$ & $\begin{array}{c}0.077^{* * *} \\
(0.007)\end{array}$ & $\begin{array}{c}0.077^{* * *} \\
(0.007)\end{array}$ & $\begin{array}{c}0.077^{* * *} \\
(0.007)\end{array}$ \\
\hline Exporter & $\begin{array}{c}0.133^{* * *} \\
(0.010)\end{array}$ & $\begin{array}{c}0.131^{* * *} \\
(0.010)\end{array}$ & $\begin{array}{c}0.130^{* * *} \\
(0.010)\end{array}$ & $\begin{array}{c}0.131^{* * *} \\
(0.010)\end{array}$ \\
\hline Country-industry FE & yes & yes & yes & yes \\
\hline Country-industry cluster & yes & yes & yes & yes \\
\hline Obs. & $6,852,326$ & $6,852,326$ & $6,852,326$ & $6,852,326$ \\
\hline $\mathrm{R}$ square & 0.07 & 0.07 & 0.07 & 0.07 \\
\hline Root MSE & 1.47 & 1.47 & 1.47 & 1.47 \\
\hline
\end{tabular}

Notes: OLS estimates reported. Clustered standard errors in parentheses, ${ }^{* * *} \mathrm{p}<0.01,{ }^{* *} \mathrm{p}<0.05,{ }^{*}$ $\mathrm{p}<0.1$. All regressions include country-industry fixed effect. See text for detailed descriptions of the variables. 
Table 6: The role of FDI: production linkages

(Dependent variable: Percentage change of sales)

\begin{tabular}{|c|c|c|c|c|}
\hline & $\begin{array}{l}(1) \\
\text { U.S. }\end{array}$ & $\begin{array}{c}(2) \\
\text { non-U.S. }\end{array}$ & $\begin{array}{c}(3) \\
\text { non-U.S. }\end{array}$ & $\begin{array}{c}(4) \\
\text { non-U.S. }\end{array}$ \\
\hline \multicolumn{5}{|l|}{ Ownership } \\
\hline Multi-establishment & $\begin{array}{c}0.232^{* * *} \\
(0.020)\end{array}$ & $\begin{array}{c}0.340^{* * *} \\
(0.013)\end{array}$ & $\begin{array}{c}0.341^{* * *} \\
(0.013)\end{array}$ & $\begin{array}{c}0.340^{* * *} \\
(0.013)\end{array}$ \\
\hline Foreign MNC & $\begin{array}{c}0.902^{* * *} \\
(0.102)\end{array}$ & $\begin{array}{c}0.267^{* * *} \\
(0.037)\end{array}$ & $\begin{array}{c}0.262^{* * *} \\
(0.037)\end{array}$ & $\begin{array}{c}0.269^{* * *} \\
(0.042)\end{array}$ \\
\hline x Horizontal & $\begin{array}{c}0.614 \\
(0.678)\end{array}$ & $\begin{array}{c}-0.146^{* *} \\
(0.071)\end{array}$ & $\begin{array}{l}-0.118 \\
(0.162)\end{array}$ & $\begin{array}{l}-0.065 \\
(0.077)\end{array}$ \\
\hline x Horizontal x Est. host-industry performance & & & $\begin{array}{c}0.024 \\
(0.274)\end{array}$ & \\
\hline x Horizontal x Est. home-host diff. in performance & & & & $\begin{array}{c}0.325^{* *} \\
(0.156)\end{array}$ \\
\hline x Vertical & $\begin{array}{c}0.302 \\
(0.266)\end{array}$ & $\begin{array}{l}-0.099 \\
(0.102)\end{array}$ & $\begin{array}{c}0.174^{* * *} \\
(0.067)\end{array}$ & $\begin{array}{c}0.063 \\
(0.120)\end{array}$ \\
\hline x Vertical x Est. host-industry performance & & & $\begin{array}{c}-0.370^{* * *} \\
(0.105)\end{array}$ & \\
\hline x Vertical x Est. home-host diff. in performance & & & & $\begin{array}{c}0.341^{* *} \\
(0.176)\end{array}$ \\
\hline Domestic MNC & $\begin{array}{c}0.419^{* * *} \\
(0.050)\end{array}$ & $\begin{array}{c}0.345^{* * *} \\
(0.029)\end{array}$ & $\begin{array}{c}0.345^{* * *} \\
(0.029)\end{array}$ & $\begin{array}{c}0.345^{* * *} \\
(0.029)\end{array}$ \\
\hline \multicolumn{5}{|l|}{ Economic characteristics } \\
\hline Sales & $\begin{array}{c}-0.067^{* * *} \\
(0.004)\end{array}$ & $\begin{array}{c}-0.165^{* * *} \\
(0.007)\end{array}$ & $\begin{array}{c}-0.165^{* * *} \\
(0.007)\end{array}$ & $\begin{array}{c}-0.165^{* * *} \\
(0.007)\end{array}$ \\
\hline Age & $\begin{array}{c}0.031^{* * *} \\
(0.006)\end{array}$ & $\begin{array}{c}-0.134^{* * *} \\
(0.012)\end{array}$ & $\begin{array}{c}-0.134^{* * *} \\
(0.012)\end{array}$ & $\begin{array}{c}-0.133^{* * *} \\
(0.012)\end{array}$ \\
\hline Multiproduct & $\begin{array}{c}0.051^{* * *} \\
(0.004)\end{array}$ & $\begin{array}{c}0.077^{* * *} \\
(0.007)\end{array}$ & $\begin{array}{c}0.077^{* * *} \\
(0.007)\end{array}$ & $\begin{array}{c}0.076^{* * *} \\
(0.007)\end{array}$ \\
\hline Exporter & $\begin{array}{c}0.221^{* * *} \\
(0.073)\end{array}$ & $\begin{array}{c}0.132^{* * *} \\
(0.010)\end{array}$ & $\begin{array}{c}0.131^{* * *} \\
(0.010)\end{array}$ & $\begin{array}{c}0.133^{* * *} \\
(0.010)\end{array}$ \\
\hline Country-industry FE & yes & yes & yes & yes \\
\hline Country-industry cluster & yes & yes & yes & yes \\
\hline Obs. & $5,364,640$ & $6,852,326$ & $6,852,326$ & $6,852,326$ \\
\hline $\mathrm{R}$ square & 0.03 & 0.07 & 0.07 & 0.07 \\
\hline Root MSE & 0.87 & 1.47 & 1.47 & 1.47 \\
\hline
\end{tabular}

Notes: OLS estimates reported. Clustered standard errors in parentheses, ${ }^{* * *} \mathrm{p}<0.01,{ }^{* *} \mathrm{p}<0.05,{ }^{*}$ $\mathrm{p}<0.1$. All regressions include country-industry fixed effect. See text for detailed descriptions of the variables. 
Table 7: The role of FDI: financial dependence

(Dependent variable: Percentage change of sales)

\begin{tabular}{lcccc}
\hline \hline & $(1)$ & $(2)$ & $(3)$ & $(4)$ \\
& U.S. & non-U.S. & non-U.S. & non-U.S. \\
\hline Ownership & & & & \\
Multi-establishment & $0.229^{* * *}$ & $0.342^{* * *}$ & $0.342^{* * *}$ & $0.342^{* * *}$ \\
& $(0.020)$ & $(0.013)$ & $(0.013)$ & $(0.013)$ \\
Foreign MNC & $0.857^{* * *}$ & $0.192^{* * *}$ & $0.190^{* * *}$ & $0.178^{* * *}$ \\
& $(0.138)$ & $(0.037)$ & $(0.037)$ & $(0.037)$ \\
x Financial dep. & $0.346^{*}$ & $0.219^{*}$ & 0.167 & $0.456^{* * *}$ \\
& $(0.178)$ & $(0.132)$ & $(0.147)$ & $(0.143)$ \\
x Fin. dep. x host-country credit change & & & $-0.178^{* *}$ & \\
& & & $(0.082)$ & \\
x Fin. dep. x home-host diff. in credit change & & & & $0.141^{* * *}$ \\
& & & & $(0.045)$ \\
Domestic MNC & & & & \\
& & & & \\
Economic characteristics & $(0.050)$ & $(0.029)$ & $(0.029)$ & $(0.029)$ \\
Sales & & & & \\
& $-0.063^{* * *}$ & $-0.164^{* * *}$ & $-0.164^{* * *}$ & $-0.164^{* * *}$ \\
Age & $(0.004)$ & $(0.007)$ & $(0.007)$ & $(0.007)$ \\
& $0.029^{* * *}$ & $-0.139^{* * *}$ & $-0.139^{* * *}$ & $-0.139^{* * *}$ \\
Multiproduct & $(0.006)$ & $(0.011)$ & $(0.011)$ & $(0.011)$ \\
Exporter & $0.049^{* * *}$ & $0.079^{* * *}$ & $0.079^{* * *}$ & $0.079^{* * *}$ \\
Country-industry FE & $(0.004)$ & $(0.007)$ & $(0.007)$ & $(0.007)$ \\
Country-industry cluster & $0.228^{* * *}$ & $0.131^{* * *}$ & $0.131^{* * *}$ & $0.131^{* * *}$ \\
Obs. & $(0.075)$ & $(0.010)$ & $(0.010)$ & $(0.010)$ \\
R square & yes & yes & yes & yes \\
Root MSE & yes & yes & yes & yes \\
\hline \hline & $5,093,313$ & $6,645,943$ & $6,645,943$ & $6,645,943$ \\
& 0.03 & 0.07 & 0.07 & 0.07 \\
& 0.87 & 1.46 & 1.46 & 1.46 \\
\hline
\end{tabular}

Notes: OLS estimates reported. Clustered standard errors in parentheses, ${ }^{* * *} \mathrm{p}<0.01,{ }^{* *} \mathrm{p}<0.05,{ }^{*}$ $\mathrm{p}<0.1$. All regressions include country-industry fixed effect. See text for detailed descriptions of the variables. 
Table 8: The role of FDI: multinational networks

(Dependent variable: Percentage change of sales)

\begin{tabular}{|c|c|c|c|c|}
\hline & $\begin{array}{l}\text { (1) } \\
\text { U.S. }\end{array}$ & $\begin{array}{c}(2) \\
\text { non-U.S. }\end{array}$ & $\begin{array}{c}(3) \\
\text { non-U.S. }\end{array}$ & $\begin{array}{c}(4) \\
\text { non-U.S. }\end{array}$ \\
\hline \multicolumn{5}{|l|}{ Ownership } \\
\hline Multi-establishment & $\begin{array}{c}0.233^{* * *} \\
(0.020)\end{array}$ & $\begin{array}{c}0.342^{* * *} \\
(0.013)\end{array}$ & $\begin{array}{c}0.341^{* * *} \\
(0.013)\end{array}$ & $\begin{array}{c}0.342^{* * *} \\
(0.013)\end{array}$ \\
\hline Foreign MNC & $\begin{array}{c}0.899^{* * *} \\
(0.140)\end{array}$ & $\begin{array}{c}0.177^{* * *} \\
(0.032)\end{array}$ & $\begin{array}{c}0.159 * * * \\
(0.032)\end{array}$ & $\begin{array}{c}0.171^{* * *} \\
(0.032)\end{array}$ \\
\hline x Network & $\begin{array}{c}0.003 \\
(0.012)\end{array}$ & $\begin{array}{c}0.006^{* * *} \\
(0.002)\end{array}$ & $\begin{array}{c}0.023^{* * *} \\
(0.003)\end{array}$ & $\begin{array}{c}0.005^{* * *} \\
(0.002)\end{array}$ \\
\hline x Network x Est. host-industry performance & & & $\begin{array}{c}-0.023^{* * *} \\
(0.004)\end{array}$ & \\
\hline x Network x Host-country credit change & & & & $\begin{array}{c}-0.005^{* * *} \\
(0.001)\end{array}$ \\
\hline Domestic MNC & $\begin{array}{c}0.414^{* * *} \\
(0.068)\end{array}$ & $\begin{array}{c}0.283^{* * *} \\
(0.034)\end{array}$ & $\begin{array}{c}0.285^{* * *} \\
(0.034)\end{array}$ & $\begin{array}{c}0.271^{* * *} \\
(0.034)\end{array}$ \\
\hline x Network & $\begin{array}{c}0.001 \\
(0.007)\end{array}$ & $\begin{array}{c}0.009^{* * *} \\
(0.003)\end{array}$ & $\begin{array}{c}0.036^{* * *} \\
(0.006)\end{array}$ & $\begin{array}{c}0.028^{* * *} \\
(0.011)\end{array}$ \\
\hline x Network x Est. domestic-industry performance & & & $\begin{array}{c}-0.058^{* * *} \\
(0.013)\end{array}$ & \\
\hline x Network x Domestic credit change & & & & $\begin{array}{c}0.008^{* *} \\
(0.004)\end{array}$ \\
\hline \multicolumn{5}{|l|}{ Economic characteristics } \\
\hline Sales & $\begin{array}{c}-0.067^{* * *} \\
(0.004)\end{array}$ & $\begin{array}{c}-0.165^{* * *} \\
(0.007)\end{array}$ & $\begin{array}{c}-0.165^{* * *} \\
(0.007)\end{array}$ & $\begin{array}{c}-0.165^{* * * *} \\
(0.007)\end{array}$ \\
\hline Age & $\begin{array}{c}0.031^{* * *} \\
(0.006)\end{array}$ & $\begin{array}{c}-0.134^{* * *} \\
(0.012)\end{array}$ & $\begin{array}{c}-0.134^{* * *} \\
(0.012)\end{array}$ & $\begin{array}{c}-0.134^{* * *} \\
(0.012)\end{array}$ \\
\hline Multiproduct & $\begin{array}{c}0.051^{* * *} \\
(0.004)\end{array}$ & $\begin{array}{c}0.077^{* * *} \\
(0.007)\end{array}$ & $\begin{array}{c}0.077^{* * *} \\
(0.007)\end{array}$ & $\begin{array}{c}0.077^{* * *} \\
(0.007)\end{array}$ \\
\hline Exporter & $\begin{array}{c}0.221^{* * *} \\
(0.073)\end{array}$ & $\begin{array}{c}0.131^{* * *} \\
(0.010)\end{array}$ & $\begin{array}{c}0.130^{* * *} \\
(0.010)\end{array}$ & $\begin{array}{c}0.130^{* * *} \\
(0.010)\end{array}$ \\
\hline Country-industry FE & yes & yes & yes & yes \\
\hline Country-industry cluster & yes & yes & yes & yes \\
\hline Obs. & $5,364,640$ & $6,852,326$ & $6,852,326$ & $6,852,326$ \\
\hline $\mathrm{R}$ square & 0.03 & 0.07 & 0.07 & 0.07 \\
\hline Root MSE & 0.87 & 1.47 & 1.47 & 1.47 \\
\hline
\end{tabular}

Notes: OLS estimates reported. Clustered standard errors in parentheses, ${ }^{* * *} \mathrm{p}<0.01,{ }^{* *} \mathrm{p}<0.05,{ }^{*}$ $\mathrm{p}<0.1$. All regressions include country-industry fixed effect. See text for detailed descriptions of the variables. 
Table 9: Interdependence in the network

(Dependent variable: Percentage change of sales)

\begin{tabular}{|c|c|c|c|c|}
\hline & $\begin{array}{l}\text { (1) } \\
\text { U.S. }\end{array}$ & $\begin{array}{l}\text { (2) } \\
\text { U.S. }\end{array}$ & $\begin{array}{c}(3) \\
\text { non-U.S. }\end{array}$ & $\begin{array}{c}4) \\
\text { non-U.S. }\end{array}$ \\
\hline \multicolumn{5}{|l|}{ Ownership } \\
\hline Multi-establishment & $\begin{array}{c}0.231^{* * *} \\
(0.020)\end{array}$ & $\begin{array}{c}0.231^{* * * *} \\
(0.020)\end{array}$ & $\begin{array}{c}0.342^{* * *} \\
(0.013)\end{array}$ & $\begin{array}{c}0.337^{* * *} \\
(0.013)\end{array}$ \\
\hline Foreign MNC & $\begin{array}{c}2.385^{* *} \\
(1.283)\end{array}$ & $\begin{array}{c}0.428 \\
(0.476)\end{array}$ & $\begin{array}{c}0.177^{* * *} \\
(0.032)\end{array}$ & $\begin{array}{c}0.327^{* * *} \\
(0.146)\end{array}$ \\
\hline x Network & $\begin{array}{c}0.127 \\
(0.172)\end{array}$ & $\begin{array}{c}0.048 \\
(0.041)\end{array}$ & $\begin{array}{c}0.007^{* * *} \\
(0.002)\end{array}$ & $\begin{array}{c}0.013^{* *} \\
(0.006)\end{array}$ \\
\hline x Horizontal network & $\begin{array}{c}-0.704 \\
(0.513)\end{array}$ & $\begin{array}{c}-0.142 \\
(0.126)\end{array}$ & $\begin{array}{l}-0.007 \\
(0.008)\end{array}$ & $\begin{array}{l}-0.018 \\
(0.013)\end{array}$ \\
\hline x Network ave. est. performance & & $\begin{array}{c}0.093 \\
(1.028)\end{array}$ & & $\begin{array}{c}0.035 \\
(0.278)\end{array}$ \\
\hline x Horizontal network ave. est. performance & & $\begin{array}{l}-0.009 \\
(0.313)\end{array}$ & & $\begin{array}{c}-0.415^{* * *} \\
(0.157)\end{array}$ \\
\hline Domestic MNC & $\begin{array}{c}0.478^{* * *} \\
(0.108)\end{array}$ & $\begin{array}{c}0.136 \\
(0.177)\end{array}$ & $\begin{array}{c}0.287^{* * *} \\
(0.034)\end{array}$ & $\begin{array}{c}0.690^{* * *} \\
(0.308)\end{array}$ \\
\hline x Network & $\begin{array}{c}0.009 \\
(0.010)\end{array}$ & $\begin{array}{c}0.007 \\
(0.010)\end{array}$ & $\begin{array}{c}0.009^{* * *} \\
(0.003)\end{array}$ & $\begin{array}{l}-0.007 \\
(0.010)\end{array}$ \\
\hline x Horizontal network & $\begin{array}{c}-0.014^{* * *} \\
(0.004)\end{array}$ & $\begin{array}{c}-0.010^{* *} \\
(0.005)\end{array}$ & $\begin{array}{c}-0.004^{* * *} \\
(0.002)\end{array}$ & $\begin{array}{c}-0.007^{*} \\
(0.004)\end{array}$ \\
\hline x Network ave. est. performance & & $\begin{array}{c}-0.231 \\
(0.716)\end{array}$ & & $\begin{array}{l}-0.949 \\
(0.599)\end{array}$ \\
\hline x Horizontal network ave. est. performance & & $\begin{array}{c}0.647 \\
(0.680)\end{array}$ & & $\begin{array}{c}0.023 \\
(0.256)\end{array}$ \\
\hline Economic characteristics & & & & \\
\hline Sales & $\begin{array}{c}-0.067^{* * *} \\
(0.004)\end{array}$ & $\begin{array}{c}-0.067^{* * *} \\
(0.004)\end{array}$ & $\begin{array}{c}-0.165^{* * *} \\
(0.007)\end{array}$ & $\begin{array}{c}-0.165^{* * *} \\
(0.007)\end{array}$ \\
\hline Age & $\begin{array}{c}0.032^{* * *} \\
(0.006)\end{array}$ & $\begin{array}{c}0.032^{* * *} \\
(0.006)\end{array}$ & $\begin{array}{c}-0.134^{* * *} \\
(0.012)\end{array}$ & $\begin{array}{c}-0.132^{* * *} \\
(0.012)\end{array}$ \\
\hline Multiproduct & $\begin{array}{c}0.051^{* * *} \\
(0.004)\end{array}$ & $\begin{array}{c}0.051^{* * *} \\
(0.004)\end{array}$ & $\begin{array}{c}0.077^{* * *} \\
(0.007)\end{array}$ & $\begin{array}{c}0.076^{* * *} \\
(0.007)\end{array}$ \\
\hline Exporter & $\begin{array}{c}0.236^{* * *} \\
(0.077)\end{array}$ & $\begin{array}{c}0.243^{* * *} \\
(0.080)\end{array}$ & $\begin{array}{c}0.131^{* * *} \\
(0.010)\end{array}$ & $\begin{array}{c}0.132^{* * *} \\
(0.010)\end{array}$ \\
\hline Country-industry FE & yes & yes & yes & yes \\
\hline Country-industry cluster & yes & yes & yes & yes \\
\hline Obs. & $5,364,640$ & $5,364,640$ & $6,852,326$ & $6,852,326$ \\
\hline $\mathrm{R}$ square & 0.03 & 0.03 & 0.07 & 0.07 \\
\hline Root MSE & 0.86 & 0.86 & 1.47 & 1.46 \\
\hline
\end{tabular}

Notes: OLS estimates reported. Clustered standard errors in parentheses, ${ }^{* * *} \mathrm{p}<0.01,{ }^{* *} \mathrm{p}<0.05,{ }^{*}$ $\mathrm{p}<0.1$. All regressions include country-industry fixed effect. See text for detailed descriptions of the variables. 
Table 10: Matching analysis (Dependent variable: Percentage change of sales)

\begin{tabular}{lcc}
\hline \hline & $(1)$ & $(2)$ \\
& U.S. & non-U.S. \\
\hline Ownership & & \\
Foreign MNC & $0.725^{* * *}$ & $0.192^{* * *}$ \\
& $(0.107)$ & $(0.029)$ \\
Country-industry FE & yes & yes \\
Number of treated & 2,132 & 25,589 \\
Number of controls & 2,002 & 16,685 \\
\hline \hline
\end{tabular}

Notes: OLS estimates reported. Bootstrapped standard errors in parentheses. ${ }^{* * *} \mathrm{p}<0.01,{ }^{* *} \mathrm{p}<0.05$, $* \mathrm{p}<0.1$. 